\title{
约 \\ PLENARINHO: NOVOS PARADIGMAS PARA NOVAS GERAÇÕES \\ PLENARINHO: NEW PARADIGMS FOR NEW GENERATIONS
}

Ana Marusia Pinheiro Lima Meneguin*

Resumo: Este estudo faz um resgate histórico do programa infantojuvenil Plenarinho, da Câmara dos Deputados, e documenta o processo de reflexão sobre seu propósito. Analisa-se o que é oferecido pelo Portal Plenarinho na internet, nas dimensões tecnológica, comunicacional, educacional e política. Em seguida, avaliam-se os projetos inscritos no Câmara Mirim, observando-se o letramento político das crianças, segundo requisitos de Crick (1998). A metodologia consiste em pesquisa documental e análise de conteúdo. Os resultados mostram a evolução do programa, referência no Brasil e no mundo, e os desafios que ainda se impõem para sua continuidade, pertinentes tanto para a literatura quanto para a realização de iniciativas semelhantes.

Palavras-chave: Plenarinho; Câmara dos Deputados; Letramento político; Internet; Criança

Abstract: Plenarinho is the program of Brazilian Chamber of Deputies for children. This paper documents its history and the reflection process about its purpose. It analyzes what Plenarinho offers in its portal on the internet, through the dimensions of technology, communication, education, and politics. After this, it evaluates the bill propositions sent to the contest "Câmara Mirim," observing the political literacy of children, according to Crick's requirements (1998). The methodology consists of documentary research and content analysis. The results show the evolution of a program that is a reference in Brasil and the world, as well as the challenges it still needs to face to keep going, which are relevant for both literature and similar initiatives.

Keywords: Plenarinho; Brazilian Chamber of Deputies; Political literacy; Internet; Children

\section{Introdução}

O objeto desta pesquisa é o Plenarinho, programa de relacionamento da Câmara dos Deputados com o público infantojuvenil. O programa ancora-se no portal na internet (www.plenarinho.leg.br) e inclui ações presenciais, bem como a produção e a distribuição de material impresso.

$\mathrm{O}$ trabalho divide-se em três fases. A primeira faz o exame do Portal Plenarinho na internet, observando o que é oferecido em quatro dimensões: tecnológica, comunicacional, educacional e política. Entende-se que as três primeiras dimensões são requisitos necessários para que se alcance a quarta - que traduz o propósito do programa.

Desde 2013, o Plenarinho está em processo de reformulação dessas quatro dimensões, iniciando com a reflexão sobre a arquitetura da informação, as rotinas de produção, até abarcar

\footnotetext{
* Doutoranda em Ciência Política e Mestre em Comunicação (2003), Bacharel em Arquitetura e Urbanismo pela Universidade de Brasília (1995) e em Comunicação Social pelo Centro Universitário de Brasília (1993). Analista Legislativa da Câmara dos Deputados e pesquisadora do Programa de Pós-graduação do Centro de Formação, Treinamento e Aperfeiçoamento (anamarusia@ hotmail.com).
} 
os próprios paradigmas em que o Plenarinho estava fundamentado. Os novos preceitos rumam em direção ao maior engajamento do público infantil na participação política.

A segunda etapa avalia os projetos inscritos no Câmara Mirim, especificamente a edição 2013, como retorno das crianças quanto à participação proposta. Trata-se de uma ação em que crianças elaboram, discutem e votam projetos de lei de sua autoria, em uma simulação da atividade legislativa. Na análise, procura-se extrair elementos que demonstrem se os objetivos do Plenarinho estão sendo abarcados e se o letramento político dos participantes é alcançado, de acordo com os requisitos propostos por Crick (1998).

Em cada uma das quatro dimensões, será feita a comparação entre as características iniciais e atuais do programa, com seus pontos positivos e negativos. Além disso, apresentam-se sugestões para o aperfeiçoamento do Plenarinho, diante de mudanças de contexto e dos seus próprios paradigmas.

Por último, o artigo expõe os desafios que o programa enfrenta, com os quais precisa lidar para continuar evoluindo, ou mesmo existindo.

A metodologia consiste em pesquisa bibliográfica, documental e análise de conteúdo. Os dados são compilados do Google Analytics e de relatórios do Plenarinho. Critérios propostos por diversos autores (STOCKDALE; BOROVICKA, 2006; SILVA, 2009; O'REILLY, 2005; PINHO, 1990; SANTOS, 2012; ACKERMANN et al., 2003) caracterizam uma abordagem metodológica interdisciplinar e especificamente empírica para as primeiras três dimensões. A dimensão política, a mais importante, por ser a distintiva do Plenarinho, conta com o respaldo da literatura sobre letramento político.

O Plenarinho é um rico objeto de pesquisa. Lançado em 2004, continua ativo e em contínuo processo de transformação. Combina uma interface digital robusta com ações presenciais junto ao público infantil, sendo referência no Brasil e no mundo (A HANDBOOK... 2011). A reprodução desse percurso e o detalhamento da análise, discriminando recursos atuais e propostas para a nova plataforma, são interessantes para trabalhos futuros, tanto na implantação de iniciativas com objetivos semelhantes aos do Plenarinho, quanto para estudos desse tipo de ação.

Ressalte-se que não faz parte do escopo deste artigo aprofundar a análise em cada uma das quatro dimensões. Primeiro, pela limitação do espaço. Segundo, porque a intenção é oferecer um panorama histórico e conceitual do Plenarinho, que possa servir de ponto de partida para gestores em casas legislativas, educadores e pesquisadores.

A maneira com que este trabalho foi estruturado, aliás, é o seu primeiro achado. O Plenarinho já foi objeto de outras pesquisas nos âmbitos tecnológico (SILVA, 2009), comunicacional (COSTA; MELO, 2010), educacional (MONTEIRO, 2015) e político (MELO, 2008; MARTINS, 2012). Nenhuma delas, no entanto, estabeleceu pontes para o letramento político, sendo essa uma das contribuições deste artigo. 


\section{Letramento Político}

Segundo Crick (1998), letramento político é a aprendizagem sobre como as pessoas podem se fazer atuantes na vida pública, por meio de conhecimento, habilidades e valores. Para ele, a vida pública aborda conhecimento realista, preparação para a resolução de conflitos e tomada de decisões, relativos aos problemas sociais e econômicos atuais, incluindo as expectativas individuais de cada um, a preparação para o mercado de trabalho, a discussão sobre a alocação de recursos públicos e a racionalidade dos impostos, entre outros.

Cosson (2008) completa, enfatizando a urgência de se pensar sobre as transformações sociais das últimas décadas, que levaram ao questionamento dos poderes e limites do Estado e da própria noção de cidadania, anteriormente vinculada à identificação nacional e à obediência a regras coletivas. Dentre as transformações, ele cita o impacto da globalização de economias e culturas, o processo de exclusão de parte da população dos benefícios sociais, a fragmentação e a ascendência de novas identidades. Essa ascendência é notadamente importante quando se trata das novas gerações.

Nessa linha, Crick (1998) apresenta os elementos essenciais que devem ser alcançados no letramento político. $\mathrm{O}$ autor salienta a importância de se abranger todos os elementos, mas não necessariamente todos de uma só vez.

Quadro 1 - Elementos do letramento político ${ }^{1}$

\begin{tabular}{|c|c|c|c|}
\hline Conceitos-chave & Valores e disposições & $\begin{array}{l}\text { Habilidades e } \\
\text { atitudes }\end{array}$ & $\begin{array}{c}\text { Conhecimento e } \\
\text { entendimento }\end{array}$ \\
\hline \multirow{3}{*}{$\begin{array}{l}\text { Democracia e } \\
\text { autocracia }\end{array}$} & Interesse no bem comum & \multirow{3}{*}{$\begin{array}{l}\text { Capacidade de } \\
\text { considerar e apreciar a } \\
\text { experiência e a } \\
\text { perspectiva dos outros }\end{array}$} & $\begin{array}{l}\text { Natureza das } \\
\text { comunidades } \\
\text { democráticas }\end{array}$ \\
\hline & $\begin{array}{l}\text { Abertura à mudança de } \\
\text { opiniões e atitudes diante } \\
\text { do debate e da evidência }\end{array}$ & & $\begin{array}{l}\text { Parlamentos nos níveis } \\
\text { local, estadual, } \\
\text { nacional, continental e } \\
\text { internacional }\end{array}$ \\
\hline & $\begin{array}{l}\text { Comprometimento com a } \\
\text { cidadania ativa }\end{array}$ & & $\begin{array}{l}\text { Questões e } \\
\text { acontecimentos tópicos } \\
\text { e contemporâneos, em } \\
\text { níveis local, estadual, } \\
\text { nacional, continental e } \\
\text { internacional }\end{array}$ \\
\hline \multirow[t]{2}{*}{$\begin{array}{l}\text { Cooperação e } \\
\text { conflito }\end{array}$} & $\begin{array}{l}\text { Disposição para trabalhar } \\
\text { com e para outros, com } \\
\text { entendimento } \\
\text { compreensivo }\end{array}$ & \multirow{2}{*}{$\begin{array}{l}\text { Capacidade para } \\
\text { cooperar e trabalhar } \\
\text { efetivamente com } \\
\text { outros }\end{array}$} & \multirow{2}{*}{$\begin{array}{l}\text { Natureza dos desafios } \\
\text { sociais, morais e } \\
\text { políticos enfrentados } \\
\text { pelos indivíduos e pelas } \\
\text { comunidades }\end{array}$} \\
\hline & $\begin{array}{l}\text { Interesse em resolver } \\
\text { conflitos }\end{array}$ & & \\
\hline
\end{tabular}

Continua

\footnotetext{
${ }^{1}$ Ressalte-se que essa disposição dos elementos não se encontra na tabela original de Crick. Eles foram reorganizados e alinhados pelos conceitos-chave no Quadro 1. Alguns itens da coluna da direita (conhecimento e entendimento) podem abarcar mais de um conceito, ou relacionar-se a mais de um valor ou habilidade.
} 


\begin{tabular}{|c|c|c|c|}
\hline Conceitos-chave & Valores e disposições & $\begin{array}{c}\text { Habilidades e } \\
\text { atitudes }\end{array}$ & $\begin{array}{l}\text { Conhecimento e } \\
\text { entendimento }\end{array}$ \\
\hline \multirow{3}{*}{$\begin{array}{l}\text { Igualdade e } \\
\text { diversidade }\end{array}$} & $\begin{array}{l}\text { Crença na dignidade } \\
\text { humana e na igualdade }\end{array}$ & \multirow{3}{*}{$\begin{array}{l}\text { Capacidade para } \\
\text { tolerar outros pontos } \\
\text { de vista }\end{array}$} & \multirow{3}{*}{$\begin{array}{l}\text { Natureza da } \\
\text { diversidade, do dissenso } \\
\text { e do conflito sociais }\end{array}$} \\
\hline & Prática da tolerância & & \\
\hline & $\begin{array}{l}\text { Comprometimento com a } \\
\text { igualdade de } \\
\text { oportunidades e de gênero }\end{array}$ & & \\
\hline \multirow{3}{*}{$\begin{array}{l}\text { Justiça, Estado de } \\
\text { Direito, leis, } \\
\text { legislação e direitos } \\
\text { humanos }\end{array}$} & $\begin{array}{l}\text { Civilidade e respeito pelo } \\
\text { Estado de Direito }\end{array}$ & \multirow{3}{*}{$\begin{array}{l}\text { Capacidade para } \\
\text { desenvolver uma } \\
\text { abordagem de } \\
\text { resolução de } \\
\text { problemas }\end{array}$} & $\begin{array}{l}\text { Contratos e questões } \\
\text { relativas aos direitos } \\
\text { humanos }\end{array}$ \\
\hline & $\begin{array}{l}\text { Julgamento e ação com } \\
\text { base em um código moral }\end{array}$ & & \multirow{2}{*}{$\begin{array}{l}\text { Direitos morais e legais } \\
\text { e responsabilidades dos } \\
\text { indivíduos e das } \\
\text { comunidades }\end{array}$} \\
\hline & $\begin{array}{l}\text { Determinação para agir } \\
\text { com justiça }\end{array}$ & & \\
\hline Liberdade e Ordem & $\begin{array}{l}\text { Esforço e iniciativa } \\
\text { individual }\end{array}$ & $\begin{array}{l}\text { Reflexão crítica sobre } \\
\text { a evidência e } \\
\text { capacidade para } \\
\text { buscar novas } \\
\text { evidências }\end{array}$ & $\begin{array}{l}\text { Direitos e } \\
\text { responsabilidades dos } \\
\text { cidadãos como } \\
\text { consumidores, } \\
\text { empregados, } \\
\text { empregadores, } \\
\text { membros da } \\
\text { comunidade e em } \\
\text { família } \\
\end{array}$ \\
\hline \multirow[t]{2}{*}{$\begin{array}{l}\text { Indivíduo e } \\
\text { comunidade }\end{array}$} & \multirow[t]{2}{*}{$\begin{array}{l}\text { Comprometimento com o } \\
\text { serviço voluntário }\end{array}$} & \multirow{2}{*}{$\begin{array}{l}\text { Capacidade para } \\
\text { utilizar, de forma } \\
\text { crítica, a mídia e a } \\
\text { tecnologia atual para } \\
\text { obter informações }\end{array}$} & $\begin{array}{l}\text { Interdependência entre } \\
\text { indivíduos e } \\
\text { comunidades locais e } \\
\text { voluntárias }\end{array}$ \\
\hline & & & $\begin{array}{l}\text { Natureza das ações } \\
\text { políticas e voluntárias } \\
\text { nas comunidades }\end{array}$ \\
\hline \multirow[b]{2}{*}{ Poder e Autoridade } & \multirow[b]{2}{*}{$\begin{array}{l}\text { Coragem para defender } \\
\text { um ponto de vista }\end{array}$} & $\begin{array}{l}\text { Capacidade de } \\
\text { argumentação verbal e } \\
\text { escrita }\end{array}$ & \multirow{2}{*}{$\begin{array}{l}\text { O sistema econômico e } \\
\text { suas relações com os } \\
\text { indivíduos e as } \\
\text { comunidades }\end{array}$} \\
\hline & & $\begin{array}{l}\text { Capacidade para } \\
\text { reconhecer formas de } \\
\text { manipulação e } \\
\text { persuasão }\end{array}$ & \\
\hline \multirow[t]{2}{*}{$\begin{array}{l}\text { Direitos e } \\
\text { responsabilidades }\end{array}$} & $\begin{array}{l}\text { Propensão para agir com } \\
\text { responsabilidade: cuidado } \\
\text { com si mesmo e os outros; } \\
\text { previsão dos efeitos } \\
\text { prováveis das ações sobre } \\
\text { os outros; aceitação de } \\
\text { responsabilidade por } \\
\text { imprevistos ou } \\
\text { consequências infelizes. }\end{array}$ & \multirow[t]{2}{*}{$\begin{array}{l}\text { Capacidade para } \\
\text { identificar desafios e } \\
\text { situações sociais, } \\
\text { morais e políticas, } \\
\text { responder a elas e } \\
\text { influenciá-las }\end{array}$} & \multirow[t]{2}{*}{$\begin{array}{l}\text { Desenvolvimento } \\
\text { sustentável e Questões } \\
\text { relativas ao meio } \\
\text { ambiente }\end{array}$} \\
\hline & $\begin{array}{l}\text { Comprometimento com o } \\
\text { meio-ambiente }\end{array}$ & & \\
\hline
\end{tabular}

Fonte: Crick (1998, p.44), com adaptações.

Crick (1988) aponta para a necessidade do estímulo ao desenvolvimento e à aplicação prática dos conceitos, valores e habilidades. Assim, é possível trabalhar a prática antes do conhecimento formal, invertendo o mecanismo usual de alguns processos educativos com crianças. A avaliação do letramento político também pode partir do que se obtém na prática para 
inferir o conhecimento implícito.

Para Fox (2012, p. 15), interpretar o mundo não é suficiente; o estudante deve entender que pode mudá-lo. Sem a transição entre o conhecimento e a prática, ou seja, a correspondência entre o que se transmite e as condições que a criança encontra em sua vida, corre-se o risco de que "o fervor político" seja "esquecido no fundo da mochila, da mesma forma que o último dever de casa".

Lockyer (2008) chama a atenção para a combinação de elementos do republicanismo (equilíbrio entre direitos e deveres) e do liberalismo (incentivo à autonomia e foco nos direitos individuais) no Relatório Crick. Audigier (2000, apud COSSON, 2008) também identifica um caráter mais individualista na concepção recente de cidadania. Arhtur e Davison (2000) têm um entendimento diferente, e recomendam que se incremente a dimensão social no letramento político proposto por Crick, para que se alcance de fato a educação para a cidadania.

Observa-se, na literatura, o interesse na efetivação e na efetividade do letramento político, ou seja, na aplicação da teoria, e com êxito. Por isso, o estudo de uma experiência prática, com duração suficiente para permitir a análise longitudinal dos acertos e das dificuldades encontradas no percurso, acrescenta valiosos insights tanto para os pesquisadores quanto para executores. É o que se pretende neste trabalho, que tem por objeto o Plenarinho.

\section{O Programa Plenarinho}

O Plenarinho é um programa de relacionamento da Câmara dos Deputados com a comunidade, de caráter educativo ${ }^{2}$, voltado para o universo infantil: crianças de 7 a 14 anos, pais e professores. O programa ancora-se no portal na internet (www.plenarinho.leg.br) e inclui as ações Câmara Mirim, Eleitor Mirim e Escola na Câmara, bem como a produção e distribuição de material impresso. Seu slogan é: "O jeito criança de ser cidadão".

De acordo com informações da página "Quem somos"3, o portal Plenarinho "informa sobre o Poder Legislativo - elaboração de leis e atuação parlamentar -, política, democracia e organização do Estado." Temas sociais e educativos relacionados ao cotidiano infantil também são abordados, como saúde, ecologia, educação, lazer e outros.

O Câmara Mirim é realizado anualmente. Crianças apresentam e votam projetos de lei de sua autoria, em uma simulação da atividade legislativa. No caso do Eleitor Mirim, a cada dois anos, professores e estudantes participam da eleição de candidatos fictícios, desde a campanha até a votação em uma urna eletrônica virtual. O Escola na Câmara é uma parceria com a Secretaria de Educação do Distrito Federal. A equipe do Plenarinho visita escolas e também recebe a visita de estudantes e professores, no Palácio do Congresso Nacional.

\footnotetext{
${ }^{2}$ Outros programas e ações de cunho educativo da Câmara dos Deputados: Parlamento Jovem, Estágio Cidadão, Estágio Visita, Estágio Participação, Escola na Câmara, Pró-Adolescente, EcoCâmara, Laboratório Hacker (oficinas), Missão Pedagógica, Oficina de Atuação no Parlamento, Educação a distância, Programa de Pós-Graduação.

${ }^{3}$ http://www.plenarinho.gov.br/plenarinho/quem-somos
} 
O Plenarinho produz e distribui a Revista do Plenarinho, com histórias em quadrinhos e passatempos; cartilhas; livretos especiais para exposições de arte na Câmara; o Estatuto da Criança e do Adolescente (ECA) em tirinhas; e materiais impressos específicos para participação em feiras ou efemérides.

\subsection{Breve histórico do Plenarinho}

2002 - O projeto "www.plenarinho.gov.br: não apenas um site, um instrumento a serviço da cidadania", elaborado por servidores da Câmara dos Deputados ${ }^{4}$, vence o Prêmio Câmara em Ideias $2002^{5}$.

2003 - A Diretoria Geral da Câmara dos Deputados publica a Portaria $\mathrm{n}^{\circ}$ 7, de 30/01/2003, para constituição do Grupo de Trabalho destinado a desenvolver o Projeto Plenarinho ${ }^{6}$.

2004 - O site é lançado. No dia do lançamento, selecionou-se uma escola pública de cada unidade da federação. Em cada escola, um deputado fez a apresentação do site e participou de um chat sobre o futuro da criança brasileira.

2005 - O programa recebe o Selo Nota 10, como reconhecimento internacional pela DHNet (Rede Direitos Humanos e Cultura) que premia os melhores sites em língua portuguesa de todo o mundo.

2005 - Lançamento do curso a distância "Plenarinho para Professores", em parceria com o Centro de Formação, Treinamento e Aperfeiçoamento (Cefor) da Câmara dos Deputados.

2005 - Publicação da primeira edição da Revista Plenarinho.

2006 - O site é alçado à categoria de portal.

2006 - Primeira edição do Câmara Mirim.

2006 - Primeira edição do Eleitor Mirim.

2008 - Assinatura de acordo de cooperação técnica com a Escola de Educação Fazendária (ESAF) e com a Organização internacional do Comércio (OIT).

2011 - Primeira edição do Escola na Câmara - Ensino Fundamental.

2013 - Reformulação da arquitetura da informação do Portal. Redefinição conceitual do programa.

\footnotetext{
${ }^{4}$ Grupo de servidores que apresentou a proposta: Elizabeth Bocchino, Sabá de Oliveira e Maria do Amparo da Silva.

${ }^{5}$ De acordo com o Regulamento da última edição, o "Prêmio Câmara em Ideias, instituído pela Portaria-DG n ${ }^{\circ} 103-\mathrm{A}$, de 2002, integra a Política de Pessoal da Câmara dos Deputados e visa estimular a participação dos servidores no aprimoramento das atividades administrativas e legislativas pela apresentação de propostas que resultem em melhoria dos serviços ou em economia de ordem processual, financeira ou material; ou, ainda, que incorporem valores do desenvolvimento sustentável na Câmara dos Deputados. [...] A Direção da Casa compromete-se a implementar o projeto vencedor, desde que haja disponibilidade orçamentária e financeira da Câmara dos Deputados e interesse da Administração Superior"

${ }^{6}$ Membros do grupo interdisciplinar: Elizabeth Bocchino (Presidência); Maria da Silva (Secretaria Geral da Mesa); Yara Depieri (Centro de Formação), Sabá de Oliveira (Dep. de Taquigrafia), Idenise Carvalho (Dep. Médico), Maria Albuquerque e Renata Sabbat (Secretaria de Comunicação), Fernando Torres e Marcos de Souza (Centro de Informática) e Renata Pereira (Centro de Documentação e Informação).
} 


\subsection{Objetivos do Plenarinho}

O Plenarinho é fruto de uma proposta de servidores da Câmara dos Deputados, apresentada em 2002. Segundo a proposta original, o programa integraria a "estratégia de melhoria da imagem da Câmara dos Deputados", oferecendo alternativas à cobertura da mídia, de ênfase notoriamente negativa. Entre os objetivos, constavam a aproximação das crianças com os deputados, a simulação do processo legislativo e o desenvolvimento do senso de cidadania.

De acordo com um documento de 2004, ano de lançamento do Plenarinho, sua meta seria "dar uma grande contribuição para a formação da cidadania no Brasil", de forma a "evitar que as novas gerações recebam ideias equivocadas sobre o Parlamento".

Nos primeiros documentos, a Câmara dos Deputados é o foco do Plenarinho. Mais recentemente, em 2010, no desenvolvimento do Mapa Estratégico (Quadro 2) e na definição da missão e dos valores do programa, nota-se a crescente abrangência do objetivo principal, deslocando-se o eixo para o empoderamento do público-alvo:

Missão: Contribuir para a formação cidadã do público infanto-juvenil brasileiro por meio de instrumentos de educação e comunicação políticolegislativa, proporcionando canais para o exercício da participação popular desse segmento da sociedade.

Visão: Ser referência no cenário nacional, contribuindo para que a Câmara dos Deputados seja reconhecida pela sociedade como instituição promotora da cidadania e fornecedora de educação político-legislativa com excelência.

Quadro 2 - Mapa estratégico do Plenarinho

\begin{tabular}{|c|c|c|}
\hline \multicolumn{3}{|c|}{ Papel Institucional } \\
\hline $\begin{array}{l}\text { Contribuir para a construção de } \\
\text { atitudes cidadãs e da consciência } \\
\text { política nas novas gerações }\end{array}$ & $\begin{array}{l}\text { Contribuir para a compreensão } \\
\text { sobre o papel e a importância do } \\
\text { Poder Legislativo }\end{array}$ & $\begin{array}{l}\text { Contribuir para o conhecimento } \\
\text { do papel institucional da Câmara } \\
\text { dos Deputados }\end{array}$ \\
\hline \multicolumn{3}{|c|}{ Público-alvo } \\
\hline $\begin{array}{l}\text { Ampliar o alcance dos produtos } \\
\text { Plenarinho junto ao público } \\
\text { infanto-juvenil }\end{array}$ & $\begin{array}{l}\text { Aperfeiçoar a interação com } \\
\text { instituições de educação }\end{array}$ & $\begin{array}{l}\text { Estimular a participação e } \\
\text { colaboração dos educadores }\end{array}$ \\
\hline \multicolumn{3}{|c|}{ Processos internos } \\
\hline $\begin{array}{l}\text { Desenvolver novos instrumentos } \\
\text { de participação virtual }\end{array}$ & $\begin{array}{l}\text { Aprimorar os meios e garantir } \\
\text { recursos para a promoção de } \\
\text { ações de aproximação com o } \\
\text { público-alvo }\end{array}$ & $\begin{array}{l}\text { Adaptar e inserir os conteúdos } \\
\text { do Plenarinho nos veículos de } \\
\text { comunicação e instrumentos de } \\
\text { educação existentes na Casa }\end{array}$ \\
\hline $\begin{array}{lcr}\begin{array}{l}\text { Desenvolver } \\
\text { fortalecer }\end{array} \text { o } \begin{array}{l}\text { parcerias } \\
\text { vínculo }\end{array} & \text { com } \\
\text { instituições } & \text { públicas } & \text { que } \\
\text { promovem a } & \text { educação para a } \\
\text { cidadania } & & \end{array}$ & $\begin{array}{l}\text { Desenvolver ações de } \\
\text { divulgação virtuais e presenciais }\end{array}$ & $\begin{array}{l}\text { Desenvolver conteúdos } \\
\text { materiais pedagógicos } \\
\text { excelência }\end{array}$ \\
\hline \multicolumn{3}{|c|}{ Pessoas e tecnologias } \\
\hline $\begin{array}{l}\text { Garantir equipe adequada com } \\
\text { competências requeridas para o } \\
\text { trabalho }\end{array}$ & $\begin{array}{l}\text { Garantir infraestrutura } \\
\text { tecnológica adequada ao pleno } \\
\text { funcionamento } \\
\text { desenvolvimento de produtos }\end{array}$ & $\begin{array}{l}\text { Garantir instalações físicas } \\
\text { adequadas }\end{array}$ \\
\hline
\end{tabular}

Fonte: Plenarinho.

Assim, segundo a Missão e o Mapa Estratégico, o Plenarinho posiciona-se rumo à "construção de atitudes cidadãs e da consciência política nas novas gerações" no Brasil, "proporcionando canais para o exercício da participação popular desse segmento da sociedade", 
ainda que mantenha a Câmara dos Deputados como núcleo institucional de referência.

A análise do Plenarinho, neste trabalho, vai considerar as abordagens advindas das discussões mais atuais sobre o papel do programa. A elas, somar-se-ão outros critérios apontados por diversos autores como condições necessárias para o sucesso desse tipo de iniciativa. A avaliação será dividida em duas etapas:

a) Análise do Portal na internet - O que é oferecido ao público-alvo, observando-se as dimensões: (1) Tecnológica, (2) Comunicacional, (3) Educacional e (4) Política. As três primeiras dimensões precisam estar bem resolvidas para que se tenha êxito na quarta. Ressalte-se ainda que essa ordem reproduz o percurso do Plenarinho: de uma ferramenta digital (1) de Relações Públicas (2) para um programa de letramento (3) político (4).

b) Análise do Letramento Político infantil - O que o público-alvo retorna ao programa. Concentrada no Câmara Mirim, pela complexidade da ação e riqueza de informações. O recorte é a edição 2013, observando-se o teor dos projetos apresentados e sua aderência aos objetivos do Plenarinho.

\section{Análise do Portal Plenarinho}

O site do Plenarinho, lançado em 2004, foi alçado à categoria de portal em 2006, com mais recursos e uma plataforma distinta de alimentação e manutenção de dados. Desde então, houve alterações de layout e configuração da página inicial, mas a arquitetura da informação se manteve.

Em 2013, a Câmara dos Deputados iniciou processo para programação do Portal Plenarinho em uma nova plataforma. O que era um procedimento para incremento e atualização dos softwares e servidores web tornou-se uma oportunidade de reflexão sobre o portal, as rotinas de produção, até abarcar os próprios paradigmas em que o Plenarinho estava fundamentado. Essa reflexão estará incluída na análise a seguir, como propostas para a nova plataforma, que poderão ser comparadas com a situação existente.

\subsection{Dimensão Tecnológica}

A primeira dimensão refere-se ao aparato tecnológico de que dispõe o portal. A Câmara dos Deputados é uma instituição de representação nacional, com sede em Brasília-DF. A dimensão Tecnológica, concretizada no portal da internet, permite que a Casa possa ter contato com o público-alvo de modo permanente.

\section{Configuração atual e estatísticas}

O tráfego no Portal Plenarinho ${ }^{7}$ varia de acordo com o ano letivo no Brasil, diminuindo nos meses de férias (janeiro, julho e dezembro), o que indica uma associação do acesso à vida

\footnotetext{
${ }^{7}$ Fonte: MELO, 2008 e Google Analytics.
} 
escolar das crianças. O pico é em setembro, coincidindo com o término das inscrições para o Câmara Mirim. O número total de visualizações de página, a partir de $2009^{8}$, se mantém entre 300 mil e 400 mil por ano.

Hoje, o menu principal do Plenarinho se divide por assuntos (Câmara, Deputado, Cidadania, Brasil, Educação, Ecologia, Saúde), outras categorias (Notícias, Sala de Leitura, Diversão, Seu Espaço) e ainda programas (Câmara Mirim) (Figuras 1 e 2).

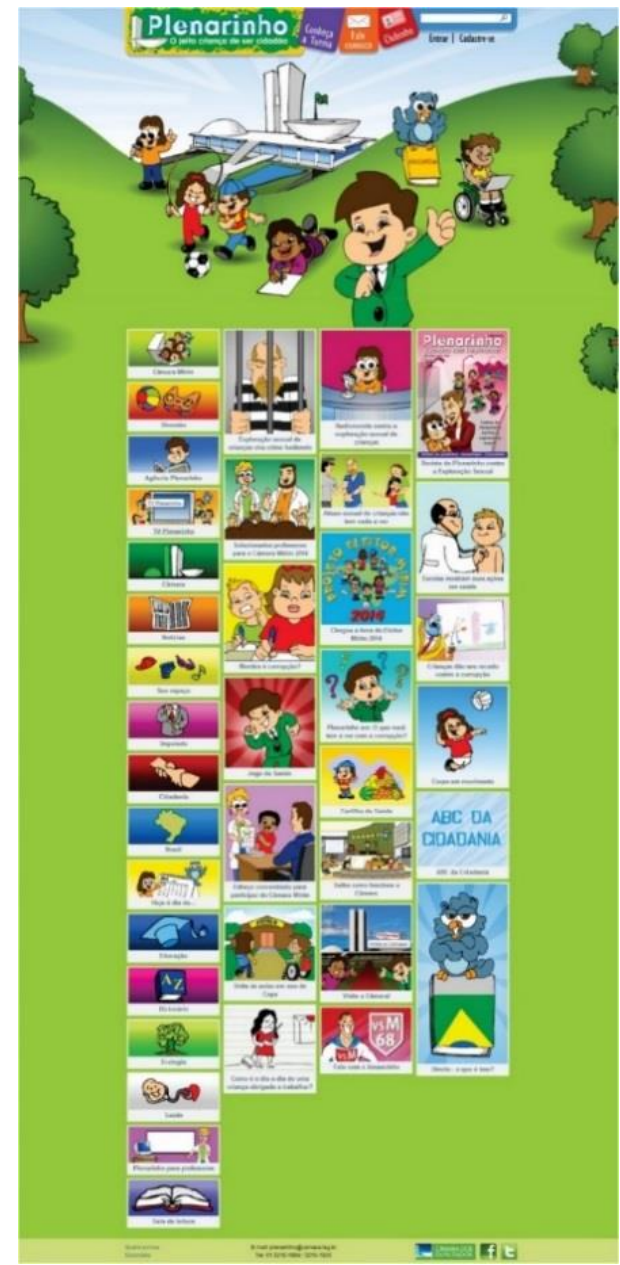

Figura 1 - Homepage

Fonte: Plenarinho.

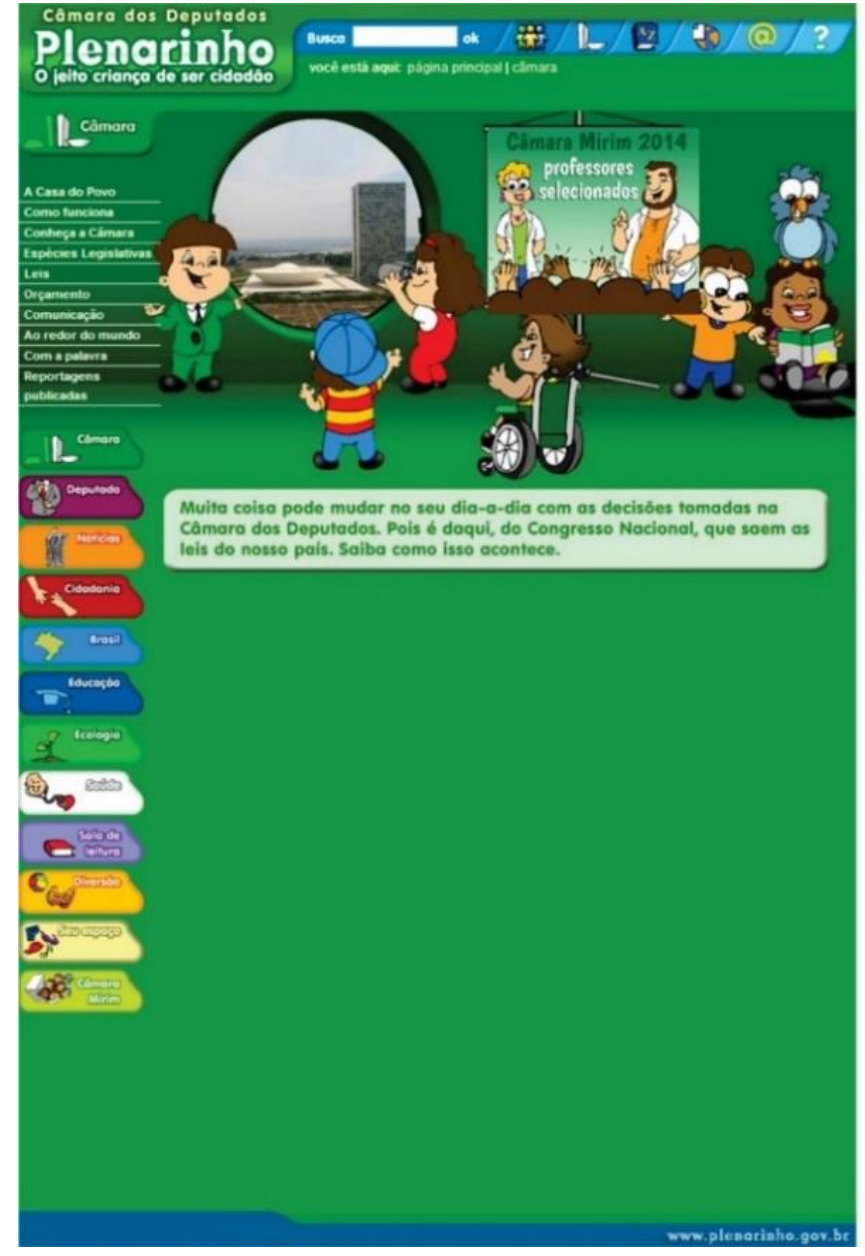

Figura 2 - Página interna: Câmara Fonte: Plenarinho.

Os produtos podem ser divididos em:

- Conteúdo formal - em grande parte, material textual informativo sobre os assuntos, que podem estar associados a outros produtos, como animações e infográficos;

- Diversão - concentração de material lúdico;

- Interação - cadastro no Clubinho, bate-papo virtual, Fale Conosco;

\footnotetext{
${ }^{8} \mathrm{O}$ pico de acessos (180 mil mensais) foi em fevereiro de 2008. A queda registrada a partir dessa data se deve à retirada, do código do portal, das informações que facilitavam o rastreamento dos mecanismos de busca. Isso foi necessário porque, em 2007, o elevado número de acessos do Plenarinho sobrecarregou os servidores web da RedeCâmara, comprometendo todos os portais a ela associados (COSTA; MELO, 2010). A partir de 2009, o número de acessos anuais se manteve.
} 
- Programas - Câmara Mirim, Eleitor Mirim;

- Educacional - voltado para o público adulto, de professores.

O gráfico 1 traz a consolidação do conteúdo mais acessado ${ }^{9}$, considerando os 100 primeiros itens. Os jogos somam, de longe, o produto mais procurado do Plenarinho. A fatia "outros" inclui revistas, passatempos, animações e a área para professores.

Gráfico 1 - Conteúdos mais acessados (8/4/2013 a 1\%/9/2013)

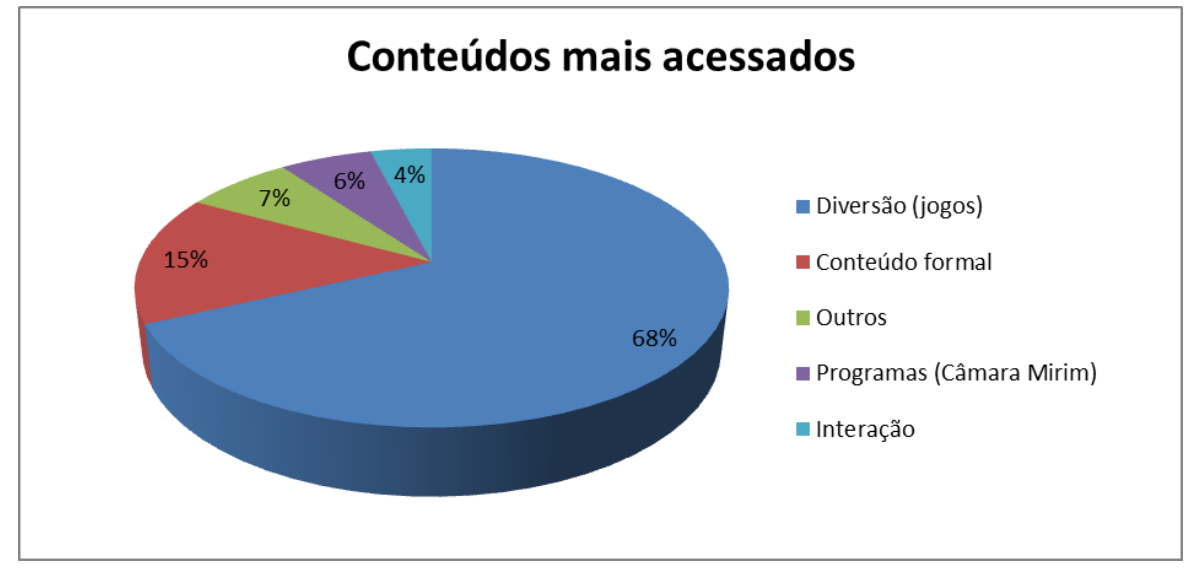

Fonte: Google Analytics.

\subsubsection{Análise da qualidade do Portal Plenarinho}

Dois critérios serão utilizados nesta análise: os de qualidade, utilizando-se o modelo de Stockdale e Borovicka (2006), baseado principalmente no trabalho de DeLone e McLean (2003); e os de comunicação digital pública, propostos por Silva (2009) para avaliar interfaces entre Estado e cidadão.

\subsection{1.a. Qualidade do sistema}

Stockdale e Borovicka (2006) enumeram os seguintes requisitos para a qualidade do sistema: Acessibilidade, Usabilidade, Funcionalidade, Responsividade, Confiabilidade, Flexibilidade, Segurança e Comunicação.

\section{Recursos atuais}

O Portal Plenarinho, ainda que esteja operando em uma plataforma obsoleta (Plone, versão 2, de 2004), atende de modo satisfatório aos requisitos de qualidade do sistema. Os pontos positivos de destaque são:

- A URL é simples e de fácil memorização, ainda que não tenha ligação clara com a Câmara dos Deputados: www.plenarinho.leg.br. ${ }^{10}$ Isso é fundamental para o

\footnotetext{
${ }^{9}$ Para a medição das estatísticas de origem de tráfego e conteúdo mais acessado no Google Analytics, optou-se por um recorte temporal: entre 8 de abril e $1^{\circ}$ de setembro de 2013, período de inscrições do Câmara Mirim, a fim de coincidir com análise do letramento político infantil (segunda parte deste estudo).

${ }^{10}$ A URL simples facilita a digitação no navegador, para acesso direto. Observa-se a diferença, por exemplo, da URL
} 
Plenarinho, porque a maior parte dos acessos (44\%) é direto, sendo o Google o segundo lugar, com $32 \%$;

- O conteúdo multimídia (texto, áudio, vídeo, foto, imagem) oferece diferentes experiências para diferentes usuários. Legendas e descrições aumentam a acessibilidade;

- O portal é seguro, condição imprescindível para a navegação de crianças (de forma a evitar a exposição excessiva e até a ação de pedófilos).

Há pontos negativos, que vão balizar as propostas para o novo portal:

- A capacidade limitada de armazenagem de dados e de tráfego do servidor web da Câmara dos Deputados;

- A quantidade e riqueza de elementos gráficos das páginas prejudica a celeridade da navegação. Além disso, há excesso no número de "cliques" até chegar à informação que se deseja;

- A disposição de banners na homepage é confusa;

- Não há busca avançada.

Além disso, o agrupamento de conteúdos de classificações distintas no menu confunde o usuário: assuntos (Câmara, Deputado, Cidadania, Brasil, Educação, Ecologia, Saúde), outras categorias (Notícias, Sala de Leitura, Diversão, Seu Espaço) e ações (Câmara Mirim). Mesmo entre os assuntos, a compartimentalização acaba por dissociar, por exemplo, Câmara e Deputado, bem como Educação e Sala de Leitura.

A área "Seu Espaço" tem o maior número de recursos para interação, como o Mural de Recados, o Seja Xereta (para envio de redações e reportagens) e o cadastro no Clubinho. Mas há outros canais dispersos pelo portal, como o "Se eu fosse deputado" (em "Deputado"), "Continue a história" (em Sala de Leitura) e o Pinga-foguinho (chat, que está no menu superior). Além disso, há reportagens fora da área de Notícias, vídeos fora da TV Plenarinho e assim por diante.

\section{Propostas para uma nova plataforma para o Plenarinho}

O foco deixará de ser o acesso pelos computadores (desktops), voltando-se para os dispositivos móveis (celulares e tablets), que é por onde a geração atual de crianças utiliza a internet. Dessa forma, a configuração, o design e o conteúdo privilegiarão as novas mídias, com o desenvolvimento de um aplicativo. A mensuração também operará de forma distinta (não tanto por acessos, medida típica da Web 1.0, mas por número de interações e downloads de recursos).

$\mathrm{O}$ portal continuará existindo, tanto para manter o legado quanto para atender às demandas de professores nos laboratórios de informática das escolas. O conteúdo será tratado para Search Engine Optimization (SEO), para facilitar a indexação pelos mecanismos de busca e

da Câmara Mirim de Florianópolis: http://www.cmf.sc.gov.br/participacao-popular/881-popular/47-camara-mirim 
a localização pelo usuário.

A arquitetura da informação será completamente reformulada. $\mathrm{O}$ menu principal vai se dividir por tipo de mídia (vídeo, áudio, história em quadrinho, jogo), facilitando o acesso aos conteúdos mais buscados. Todo o legado textual construído ao longo de uma década estará reunido à parte. $\mathrm{O}$ conteúdo formal será diferenciado das matérias factuais (notícias) com mais evidência.

A área de maior destaque será "Meu Espaço" (anteriormente "Seu Espaço"), que reunirá todas as ferramentas de interação. Receberá conteúdo produzido pelas próprias crianças, numa construção colaborativa afeita aos princípios da Web 2.0 (O'REILLY, 2005). Essa inovação não diz respeito somente ao Plenarinho. Contraditoriamente, os sites de participação política infantojuvenil têm o público-alvo como "receptor" de conteúdo, não destinando espaços para que também seja "produtor" (BANAJI; BUCKINGHAM, 2010).

\subsection{1.b. Qualidade dos serviços}

Stockdale e Borovicka (2006) citam os seguintes requisitos para a qualidade dos serviços: Percepção de qualidade do serviço, Evidência da construção de confiança, Criação de empatia, Acompanhamento de solicitações e Customização.

\section{Recursos atuais}

O destaque do Portal Plenarinho é a empatia com o público-alvo.

\section{Propostas para a nova plataforma}

Toda a identidade de marca do Plenarinho está sendo recriada, incluindo logotipos, tipografia e design dos produtos, para que fique mais contemporânea (Figura 3).

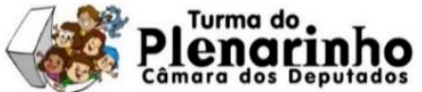

Figura 3 - Plenarinho: marcas anterior e nova Fonte: Plenarinho.

No que tange à segurança, o que hoje está ausente será incluído: publicação da Política de Privacidade e alertas de segurança. Para facilitar o atendimento aos usuários e também diminuir o número de solicitações referentes a ações simples, será disposto um FAQ.

\subsubsection{Portal Plenarinho como interface digital entre Estado e cidadão}

Silva (2009) propõe pré-requisitos que a interface digital precisa cumprir para contribuir no fortalecimento da democracia moderna. São três princípios democráticos: (1) Publicidade como tornar o Estado mais visível ao cidadão. $\mathrm{O}$ vetor da informação é predominantemente oriundo do Estado; (2) Responsividade - como tornar o Estado mais responsivo ao cidadão e caracteriza-se pelo diálogo; (3) Porosidade - como tornar o Estado mais aberto à opinião pública. 
A direção principal do fluxo comunicacional parte do cidadão.

O Plenarinho foi objeto de análise pelo próprio Silva (2009). A medição dos itens adotada mostra a predominância numérica de material de publicidade, nos níveis informativo e instrutivo. Nesse particular, o presente estudo coincide com Silva - mas as conclusões são distintas.

Em primeiro lugar, Silva (2009) não considerou as ações Eleitor Mirim e Câmara Mirim, os grandes representantes dos requisitos Responsividade e Porosidade (em parte, isso pode ser devido a falhas na arquitetura da informação do portal atual).

Em segundo lugar, ainda que tivesse computado essas ações, cada uma delas apareceria como um único item, nivelado numericamente, por exemplo, a um texto publicado sobre a Câmara dos Deputados. Entretanto, o grau de complexidade de uma ação como o Câmara Mirim é muito superior à de produção de um conteúdo de Publicidade, com envolvimento maior do público-alvo e também dos recursos humanos que lhe dão suporte.

Mesmo na plataforma atual, de 2008, a interface digital do Plenarinho já atende aos prérequisitos propostos pelo autor, ainda que de forma embrionária em alguns pontos. O legado de mais de uma década permite que agora o programa possa se dedicar mais à interação com o público-alvo, com incorporação de conteúdo colaborativo e a avaliação paulatina das ações.

É importante reiterar que o princípio de Porosidade traz aspectos menos tecnológicos e muito mais humanos. Dependem de equipe treinada e alocada para esse fim. O caso mais emblemático é o já citado Câmara Mirim. Os projetos de lei enviados pelas crianças são examinados por uma comissão de servidores da Casa. Em 2011 foram mais de 1200 inscrições, para a seleção dos três vencedores.

Tanto os critérios de Stockdale e Borovicka (2006) quanto os de Silva (2009) mensuram a qualidade de um site pelo que este oferece ao usuário final. Verifica-se, com base no que foi exposto acima, que a operacionalização de softwares e servidores web também deve propiciar facilidades de operacionalização para quem os administra. No caso do Plenarinho, a nova plataforma deve oferecer mecanismos que permitam o resgate e o cruzamento de informações recebidas em forma de relatórios sistematizados, que possam ser entregues tanto ao público-alvo (crianças e professores) quanto aos parlamentares, e mesmo à imprensa.

\subsection{Dimensão comunicacional}

No Brasil, o Plenarinho foi pioneiro na construção de conteúdo explicitamente político, voltado para crianças ${ }^{11}$, na internet. Primeiro na internet, é considerado referência para outros sites institucionais que têm a mesma finalidade.

Seis personagens foram criados para serem os porta-vozes do Plenarinho, formando uma

\footnotetext{
${ }^{11}$ Anteriormente, o assunto foi tratado em livros didáticos nas extintas disciplinas Educação Moral e Cívica e Organização Sócio-Político Brasileira (OSPB), do antigo $1^{\circ}$ grau da educação básica, sem usar linguagem infantil. Outros materiais fizeram ponte entre contos maravilhosos e o universo da política, como o musical "Os Saltimbancos" (de Luis Enríquez Bacalov, adaptado por Chico Buarque em 1977).
} 
turma. Cada personagem tem uma característica própria, com o objetivo de representar diferentes segmentos e funções na sociedade, além de personificar cada área do Portal atual (Quadro 3):

Quadro 3 - Personagens

\begin{tabular}{|c|c|c|}
\hline Personagens & Quem são & Área do Portal atual \\
\hline Zé Plenarinho e Ana Légis & Deputados & Câmara, Deputado, Cidadania \\
\hline Xereta & Repórter & Notícias \\
\hline $\begin{array}{l}\text { Edu Coruja (o único personagem } \\
\text { da turma que não é humano e é } \\
\text { adulto) }\end{array}$ & Educador & Educação, Sala de Leitura \\
\hline $\begin{array}{l}\text { Cida e Adão (cuja união de } \\
\text { nomes forma "cidadão") }\end{array}$ & $\begin{array}{l}\text { Irmãos que representam os } \\
\text { cidadãos que não detêm cargos } \\
\text { políticos }\end{array}$ & Seu Espaço, Diversão \\
\hline
\end{tabular}

Fonte: Elaborado pela autora com dados do Plenarinho.

Em 2005, um concurso com a participação de cerca de 500 crianças definiu as características do sétimo personagem, o cadeirante Vital, representante da acessibilidade. Outros aparecem em situações específicas, como a professora Josefa. Os personagens ilustram e apresentam textos, figuram em histórias e quadrinhos, animações, jogos e infográficos.

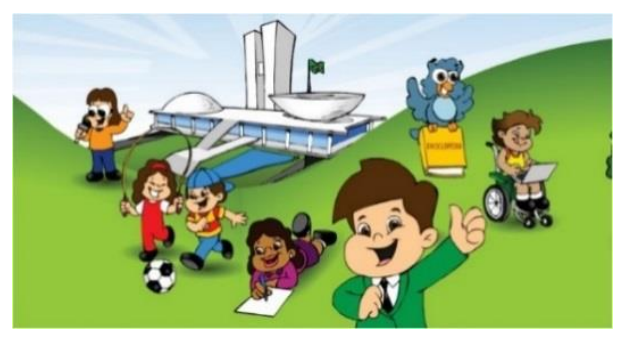

Figura 4 - Personagens originais Fonte: Plenarinho.

Sempre é válido frisar que o Plenarinho não é um projeto independente nem comercial. O lugar de fala é bem preciso, de dentro da Câmara dos Deputados, no Congresso Nacional, que é a instituição maior do Poder Legislativo federal. A responsabilidade é multiplicada, porque o público-alvo encara o conteúdo como fonte primária de conhecimento, produzido por quem tem credenciais para tal.

O desafio diário do Plenarinho é tratar um assunto, geralmente árido, de forma criativa e compreensível para as crianças, sem nunca perder de vista seu caráter institucional. Para analisar a Dimensão Comunicacional do portal, serão usados como guia os 8 Cês da boa comunicação enumerados por Cutlip e Center (apud PINHO, 1990): Credibilidade; Contexto; Conteúdo; Clareza; Continuidade; Consistência; Canais de Comunicação; e Capacidade de entendimento do público.

Da mesma forma que foi feito na Dimensão Tecnológica, estarão em paralelo a situação anterior e as perspectivas da nova plataforma.

\section{Recursos anteriores}

Entre os pontos positivos, destacam-se os canais de comunicação do Portal. Há textos 
explicativos, matérias jornalísticas, histórias em quadrinhos, animações, jogos, passatempos, fotos, imagens, infográficos, histórias em áudio e músicas. Esses formatos também estão disponíveis para envio de material pelas crianças. O Plenarinho ainda tem publicações impressas, como revistas, folderes, jogos de cartas etc.

Em nome da clareza, informações sobre Estado e legislação ganham "tradução". A grande dificuldade é abordar esses assuntos de forma simples, sem distorcê-los nem usar de "tatibitate".

A consistência é buscada sempre, com a verificação das fontes de informação.

Os pontos negativos na dimensão comunicacional incluem o fato de os sete personagens originais serem crianças com alma de adultos. Na sua descrição, por exemplo, Xereta tem a Gramática do Celso Cunha como livro de cabeceira. Dois dos personagens são deputados, e Zé Plenarinho usa terno. Nas aventuras, todos têm atitudes exemplares. Ou seja, os personagens se dividem entre o traço infantilizado e o comportamento formal, dificultando a identificação por parte das crianças e comprometendo sua credibilidade. Ainda que cada personagem tenha qualidades próprias, elas são diluídas, sem que seja possível apontar o real papel de cada um na turma.

A definição de público-alvo e sua respectiva capacidade de entendimento foram, durante muito tempo, uma preocupação do Plenarinho. A faixa etária do destinatário principal é muito extensa: 7 a 14 anos. O nível de compreensão e os interesses de uma criança que acabou de ser alfabetizada são muito diferentes dos de um adolescente. Além disso, em diversos momentos os conteúdos mostravam indecisão: se haviam sido escritos para crianças, ou para seus pais ou professores, ou para escolas e organismos internacionais. Ou para todo mundo ao mesmo tempo, o que é inviável para que a comunicação se efetive. Possivelmente como consequência dessa indefinição, a Agência de Notícias e o Clipping Criança seguem uma agenda que não pode não coincidir com os interesses reais do público-alvo.

Por fim, a continuidade da comunicação é obtida pelo recurso "Saiba mais" e links para o Glossário, quando conteúdos são relacionados manualmente. O material enviado pelos usuários não recebe tratamento. Não há metadados de correlação de conteúdo.

\section{Propostas}

O conceito de cada personagem foi recriado. Cada um tem um "superpoder" associado a um valor da cidadania, mas também um pequeno "defeito", conferindo-lhe um ar de criança sapeca, mas sem prejudicar seu reconhecimento como "mocinho" da história. Os personagens são redesenhados, com traço mais contemporâneo. A união dos poderes de cada personagem é o que vai determinar a vitória. 


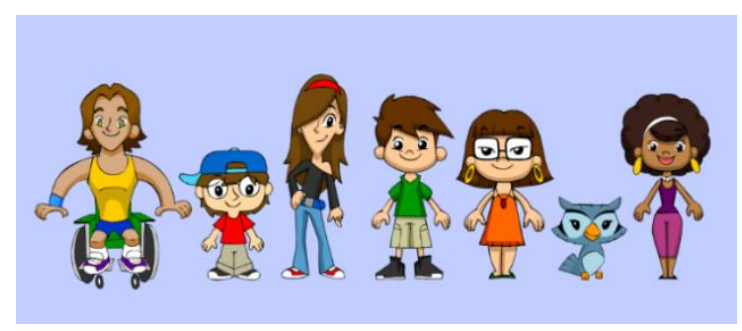

Figura 5 - Novos personagens

Fonte: Plenarinho.

Muito conteúdo já foi produzido, principalmente o de cunho informacional. A ideia agora é moderar contribuições enviadas pelo público-alvo e focar nas pautas relacionadas ao empoderamento infantil.

A Agência de Notícias e o Clipping Criança perderão a urgência e a obrigatoriedade de reproduzir todos os trâmites das matérias legislativas, enfatizando os aspectos que possam interferir de imediato a vida das crianças.

Os princípios da clareza e da consistência serão mantidos.

Para aumentar a continuidade da comunicação, poderá haver indexação por tema e tag para correlação automática de conteúdo, inclusive em diferentes tipos de mídia e material do usuário. O Glossário será mantido.

Os canais de comunicação serão mantidos, mas organizados de forma mais clara.

O conteúdo poderá ser dividido em duas faixas etárias: 7 a 10 anos e 11 a 14 anos. O material para adultos será reunido em áreas próprias.

\subsection{Dimensão Educacional}

Pelos dados de origem de tráfego do Plenarinho ${ }^{12}$, entre os 50 itens mais acessados, 21 são sites e blogs educativos. Como visto anteriormente, os acessos ao portal acompanham o ano letivo, diminuindo nas férias.

O Portal Plenarinho, portanto, mantém uma relação muito próxima com os professores e o ambiente escolar. Outros dados podem potencializar essa relação: segundo a Pesquisa TIC Kids Online Brasil 2012, a maior parte das crianças e adolescentes entre 9 e 16 anos acessa a internet na escola (42\%) e utiliza a rede para fazer trabalhos escolares (82\%). Essa mesma pesquisa traz diversos artigos sobre a importância das interfaces digitais no processo educativo.

Nesses termos, a adoção do Plenarinho na escola é algo aparentemente lógico, mas se defronta com duas dificuldades relativas ao público docente, no que tange a dois letramentos: o digital e o político.

Santos (2012) mostra que a geração atual de professores tem dificuldades para trabalhar os dispositivos digitais, principalmente a internet, em sala de aula. Utiliza recursos educacionais do século 19, para uma turma que já nasce "plugada" e assume a tecnologia como algo natural.

\footnotetext{
${ }^{12}$ Fonte: Google Analytics.
} 
Sobre o letramento político, o professor se vê diante da missão de oferecê-lo aos estudantes, sem que ele mesmo o tenha internalizado. Hart (2002, apud ACKERMANN et al., 2003) cita, por exemplo, casos de adultos que são orientados a incentivar que as crianças expressem seus pontos de vista e participem das decisões, quando eles mesmos nunca tiveram essa oportunidade.

A tensão e as disparidades de letramentos são exacerbadas no caso de uma interface como o Plenarinho, que é política e digital ao mesmo tempo. O que se recomenda como compartilhamento de poder pode ser interpretado pelo professor como perda desse poder: “[...] todo o ímpeto dos alunos é categoricamente controlado pelos professores, que confundem liberdade com desordem, criatividade com desconexão, iniciativa com rebeldia" (SANTOS, 2012, p. 83). Ao mesmo tempo, Santos (2012) assevera que a intervenção do professor é imprescindível para que a criança não fique à deriva. O estreitamento da parceria do Plenarinho com as escolas tem, então, dupla ação educativa: para estudantes e para professores. Santos (2012) também propõe maneiras de trabalhar a educação infantil nas plataformas digitais. Ele defende que não haja informação sem componente lúdico, nem conteúdo lúdico sem informação. Isso é especialmente importante para o Plenarinho.

\section{Recursos atuais}

O material informativo do Plenarinho é um aspecto positivo. Visa também a fornecer subsídios para pesquisas escolares. Vários outros produtos são publicados para atrair a atenção das crianças, na expectativa de que elas continuem navegando e se deparem com mais informações sobre política.

Como aspectos negativos, destaca-se que, apesar de existirem materiais que conjuguem diversão e informação, em relação ao que sugere Santos (2012), há textos sem ludicidade e entretenimento sem conteúdo informativo.

O Plenarinho para Professores traz alguns projetos pedagógicos. Entre 2005 e 2014, havia um curso a distância, feito em parceria com o Centro de Formação, Treinamento e Aperfeiçoamento da Câmara dos Deputados (Cefor), descontinuado pela obsolescência tecnológica e paradigmática.

Uma das preocupações - e críticas - dos professores nas escolas é a extensa grade curricular obrigatória. Existe o falso entendimento de que "cidadania" seria "mais uma disciplina". Para fazer face a essa objeção, faltam ao Plenarinho mais propostas pedagógicas que permitissem permear o letramento político no conteúdo das diversas matérias (matemática, ciências, etc.).

\section{Propostas}

Com a possibilidade de correlação automática de conteúdos, jogos, quadrinhos e outros 
estarão listados na mesma página, de acordo com o tema da matéria, propiciando a ludicidade proposta por Santos (2012). Os produtos de entretenimento serão criados sempre a partir dos elementos de Crick (Quadro 1).

As informações de caráter legislativo permanecerão (Conhecimento e Entendimento, segundo Crick, 1998), mas o destaque será o desenvolvimento de vivências democráticas no ambiente escolar. A ideia para a nova área tecnológica é ampliar a oferta de projetos pedagógicos e estabelecer uma rede virtual de troca de conteúdo e boas práticas entre escolas e educadores.

\subsection{Dimensão Política}

As três primeiras dimensões - tecnológica, comunicacional e educacional - podem estar atendidas em todas as premissas, mas, para o alcance dos objetivos do Plenarinho, não se sustentam sem a quarta - o letramento político. Contudo, esta última se potencializa com a precedência das três primeiras.

O Plenarinho, em sua plataforma, produtos e ações, deve proporcionar uma experiência democrática ao público-alvo. O programa contém todos os elementos de Crick (1998). A ênfase é nos conhecimentos e entendimentos, em especial nos que se referem à Câmara dos Deputados e ao Poder Legislativo. Mesmo assim, o portal atual satisfaz os demais critérios, principalmente em produtos como revistinhas e animações. As ações, especialmente as presenciais, fortalecem a dimensão social ao letramento político.

Cabe agora analisar o retorno das crianças em relação ao que o Plenarinho oferece. O método de investigação escolhido foi o da Análise de Conteúdo, conforme detalhada por Babbie (2000). Consiste na seleção da unidade de análise, na codificação dos conteúdos (manifestos e não manifestos), na conceituação e criação das categorias de codificação e na avaliação dos conteúdos.

Optou-se pela ação Câmara Mirim, tendo por unidades de análise os projetos de lei enviados pelas crianças.

\section{Análise do Letramento Político infantil - Câmara Mirim}

O Câmara Mirim é um concurso de projetos de lei aberto a todos os estudantes do $5^{\circ}$ ao $9^{\circ}$ ano de escolas públicas e particulares do País. Três projetos são selecionados por uma comissão de consultores legislativos da Câmara dos Deputados. Os autores vêm a Brasília-DF com as despesas pagas pela Casa, para defenderem suas propostas na Sessão Mirim, composta por outras crianças.

Entre 2006 e 2013, foram mais de 4500 projetos enviados, com destaque para 2011, quando o Plenarinho recebeu 1237 inscrições. 


\subsection{Vencedores do Câmara Mirim}

A primeira codificação nesta análise de conteúdo é o desdobramento dos projetos de lei vencedores do Câmara Mirim ${ }^{13}$. O Quadro 4 traz a seleção dos que apresentaram algum aspecto sucedâneo concreto.

Dos 24 projetos, sete foram “apadrinhados" por deputados federais e tramitam na Câmara, trazendo referências explícitas ao Câmara Mirim (no quadro são identificados com o verbo “embasar").

Há projetos dos deputados mirins que estão alinhados com outras proposições ou políticas públicas, apresentadas após as edições do Câmara Mirim. Não há como afirmar se foram a inspiração para tais propostas. De qualquer forma, isso denota que as ideias das crianças encontram sintonia com o que vem sendo tratado no cenário político nacional.

Outros projetos têm o mesmo teor de outras propostas que já tramitavam.

Quadro 4 - Seleção de projetos vencedores do Câmara Mirim e seus desdobramentos

\begin{tabular}{|c|c|c|c|c|c|}
\hline $\begin{array}{l}\mathbf{A} \\
\mathbf{n} \\
\mathbf{0}\end{array}$ & Nome $^{14}$ & $\begin{array}{l}\text { Cidade } \\
\text { / UF }\end{array}$ & Ementa & Desdobramentos & Outros \\
\hline ঠి & $\begin{array}{l}\text { Mariana } \\
\text { Vieira }\end{array}$ & $\mathrm{SC}$ & $\begin{array}{l}\text { Inclusão de Cidadania no } \\
\text { Currículo. }\end{array}$ & $\begin{array}{l}\text { PLS 2/2012 e PL } \\
4744 / 2012 \text { têm o mesmo } \\
\text { teor. }\end{array}$ & $\begin{array}{l}\text { Recebeu } 84 \% \text { de } \\
\text { votos a favor no } \\
\text { Vote na } W e b^{15}\end{array}$ \\
\hline ๖̊ & $\begin{array}{l}\text { Pedro } \\
\text { Carva- } \\
\text { lho }\end{array}$ & $\mathrm{RN}$ & $\begin{array}{l}\text { Toda criança órfã residente } \\
\text { em abrigo coletivo sem fins } \\
\text { lucrativos terá acesso } \\
\text { prioritário a vaga na rede } \\
\text { pública de ensino. }\end{array}$ & $\begin{array}{l}\text { Embasou o PL 1685/2007, } \\
\text { apensado ao PL 1579/2007. }\end{array}$ & \\
\hline స్ & $\begin{array}{l}\text { Karinne } \\
\text { Mendon } \\
\text {-ça }\end{array}$ & $\begin{array}{l}\text { Tagua- } \\
\text { tinga } \\
\text { (DF) }\end{array}$ & $\begin{array}{l}\text { Dispõe sobre o fim do } \\
\text { trabalho infantil. }\end{array}$ & $\begin{array}{l}\text { Embasou o PL } 2398 / 2007, \\
\text { apensado ao PL } 7650 / 2006 . \\
\text { Decreto } 3.597 / 2000 \\
\text { (regulamentado pelo } \\
\text { Decreto 6.481/2008) e } \\
\begin{array}{l}\text { Decreto 4.134/2002, já } \\
\text { tratavam do assunto. }\end{array}\end{array}$ & \\
\hline స్요 & $\begin{array}{l}\text { Mallena } \\
\text { Lira }\end{array}$ & $\begin{array}{l}\text { Iracema } \\
(\mathrm{CE})\end{array}$ & $\begin{array}{l}\text { Proíbe o transporte de } \\
\text { alunos em veículos abertos } \\
\text { ("paus de arara"). }\end{array}$ & $\begin{array}{l}\text { Embasou o PL 2561/2007, } \\
\text { apensado ao PL 2397/2007. }\end{array}$ & \\
\hline હે & $\begin{array}{l}\text { Larissa } \\
\text { Gonçal- } \\
\text { ves }\end{array}$ & $\begin{array}{l}\text { Belo } \\
\text { Hori- } \\
\text { zonte } \\
\text { (MG) }\end{array}$ & $\begin{array}{l}\text { Todo cidadão brasileiro } \\
\text { está sujeito às mesmas leis } \\
\text { e penalidades nela previstas } \\
\text { (fim do foro privilegiado). }\end{array}$ & $\begin{array}{l}\text { PEC } 470 / 2005 \text { já trata do } \\
\text { assunto. }\end{array}$ & $\begin{array}{l}\text { Recebeu } 74 \% \text { de } \\
\text { votos a favor no } \\
\text { Vote na } W e b^{16}\end{array}$ \\
\hline
\end{tabular}

Continua

\footnotetext{
${ }^{13}$ Para mais detalhes e acompanhamento das proposições, acessar http://www.camara.leg.br/sileg/default.asp. Para conhecer a íntegra das leis, acessar http://www2.camara.leg.br/atividade-legislativa/legislacao.

${ }^{14}$ Os nomes das crianças estão presentes no Portal Plenarinho e são amplamente divulgados pela mídia interna e externa. Os responsáveis dos vencedores assinam um termo de autorização do uso de informações pela Câmara dos Deputados, que inclui sua divulgação em qualquer meio existente ou que venha a existir.

${ }^{15} \mathrm{http}: / /$ www.votenaweb.com.br/projetos/pls-2-2012

${ }^{16} \mathrm{http}: / /$ www.votenaweb.com.br/projetos/pec-470-2005
} 


\begin{tabular}{|c|c|c|c|c|c|}
\hline $\begin{array}{l}\mathbf{A} \\
\mathbf{n} \\
\mathbf{o}\end{array}$ & Nome $^{17}$ & $\begin{array}{l}\text { Cidade } \\
\text { / UF }\end{array}$ & Ementa & Desdobramentos & Outros \\
\hline 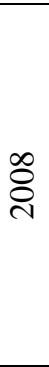 & $\begin{array}{l}\text { Stephanie } \\
\text { Ferreira }\end{array}$ & $\begin{array}{l}\text { São } \\
\text { José dos } \\
\text { Campos } \\
\text { (SP) }\end{array}$ & $\begin{array}{l}\text { As cédulas de dinheiro } \\
\text { devem trazer o valor em } \\
\text { Braille. }\end{array}$ & $\begin{array}{l}\text { PL 475/2011 tem igual teor. } \\
\text { Apensado ao PL 7699/2006, } \\
\text { que institui o Estatuto do } \\
\text { Portador de Deficiência. } \\
\text { Em 2012, o Banco Central } \\
\text { lançou notas em tamanhos } \\
\text { diferenciados para facilitar a } \\
\text { identificação pelas pessoas } \\
\text { com deficiência visual. }\end{array}$ & \\
\hline ஓి & $\begin{array}{l}\text { Richard } \\
\text { Oliveira }\end{array}$ & $\begin{array}{l}\text { São } \\
\text { José dos } \\
\text { Campos } \\
\text { (SP) }\end{array}$ & $\begin{array}{l}\text { Todos os prédios públicos a } \\
\text { serem construídos deverão } \\
\text { ter um sistema de } \\
\text { armazenamento } \\
\text { reaproveitamento de água } \\
\text { das chuvas. }\end{array}$ & $\begin{array}{l}\text { Embasou o PL 7231/2010, } \\
\text { apensado ao PL 5733/2009. }\end{array}$ & $\begin{array}{l}\text { Recebeu } 95 \% \text { de } \\
\text { votos a favor no } \\
\text { Vote na } W e b^{18}\end{array}$ \\
\hline ஓి & $\begin{array}{l}\text { Carlos } \\
\text { Marcus } \\
\text { da Silva }\end{array}$ & $\begin{array}{l}\text { Iracema } \\
(\mathrm{CE})\end{array}$ & $\begin{array}{l}\text { Estabelece requisitos para } \\
\text { ser conselheiro tutelar. }\end{array}$ & $\begin{array}{l}\text { PL 2602/2007 e PLS } \\
\text { 479/2009 têm igual teor. }\end{array}$ & $\begin{array}{l}\text { Vídeo com sua } \\
\text { história recebeu } \\
\text { o } 1^{\circ} \text { lugar no } 7^{\circ} \\
\text { Concurso } \\
\text { Causos do ECA - } \\
\text { Pró-menino, em } \\
2011^{19} \text {. }\end{array}$ \\
\hline$\stackrel{\circ}{\circ}$ & $\begin{array}{l}\text { Lorena } \\
\text { Resende }\end{array}$ & $\begin{array}{l}\text { Sobra- } \\
\text { dinho } \\
\text { (DF) }\end{array}$ & $\begin{array}{l}\text { Todos os ônibus deverão } \\
\text { ter cadeirinhas com cinto } \\
\text { de segurança para crianças } \\
\text { até cinco anos. }\end{array}$ & $\begin{array}{l}\text { Embasou o PL 7910/2010, } \\
\text { apensado ao PL 6932/2010. }\end{array}$ & $\begin{array}{l}\text { Recebeu } 75 \% \text { de } \\
\text { votos a favor no } \\
\text { Vote na } W e b^{20}\end{array}$ \\
\hline$\stackrel{\circ}{\stackrel{0}{0}}$ & $\begin{array}{l}\text { Milena } \\
\text { Silva e } \\
\text { Maria } \\
\text { Carolina } \\
\text { Rodri- } \\
\text { gues }\end{array}$ & $\begin{array}{l}\text { Campos } \\
\text { dos } \\
\text { Goy- } \\
\text { tacazes } \\
(\mathrm{RJ})\end{array}$ & $\begin{array}{l}\text { Todo deficiente visual tem } \\
\text { direito a um cão guia, sendo } \\
\text { obrigação do governo } \\
\text { federal disponibilizar cães } \\
\text { treinados. É obrigatória a } \\
\text { construção de canis de } \\
\text { adestramentos em todas as } \\
\text { capitais, com mais de } \\
100.000 \text { habitantes. }\end{array}$ & $\begin{array}{l}\text { Em nov. 2011, o Governo } \\
\text { Federal lançou a ação Viver } \\
\text { Sem Limite, que prevê a } \\
\text { implantação de Centros de } \\
\text { Treinamentos de Cães- } \\
\text { Guia. O Brasil é o único } \\
\text { País da América Latina que } \\
\text { trabalha com este tipo de } \\
\text { formação. }^{21}\end{array}$ & \\
\hline$\stackrel{\circ}{\stackrel{ }{\circ}}$ & $\begin{array}{l}\text { Patrícia } \\
\text { Rocha }\end{array}$ & $\begin{array}{l}\text { João } \\
\text { Rama- } \\
\text { lho (SP) }\end{array}$ & $\begin{array}{l}\text { Obriga a instalação de } \\
\text { dispositivo para fixação de } \\
\text { bicicletas nos prédios e } \\
\text { logradouros públicos, em } \\
\text { todos os municípios. }\end{array}$ & Embasou o PL 7909/2010. & $\begin{array}{l}\text { Recebeu } 94 \% \text { de } \\
\text { votos a favor no } \\
\text { Vote na } W e b^{22}\end{array}$ \\
\hline $\bar{\Xi}$ & $\begin{array}{l}\text { Túlio } \\
\text { Machado }\end{array}$ & $\begin{array}{l}\text { São } \\
\text { Paulo } \\
\text { (SP) }\end{array}$ & $\begin{array}{l}\text { Todo e qualquer cidadão } \\
\text { brasileiro tomará ciência do } \\
\text { quanto, em percentuais, } \\
\text { estará pagando de impostos } \\
\text { sobre qualquer produto. }\end{array}$ & $\begin{array}{l}\text { A Lei } 12.741 / 2012 \text { obriga } \\
\text { detalhamento de impostos } \\
\text { na nota fiscal. }\end{array}$ & \\
\hline
\end{tabular}

Continua

\footnotetext{
${ }^{17}$ Os nomes das crianças estão presentes no Portal Plenarinho e são amplamente divulgados pela mídia interna e externa. Os responsáveis dos vencedores assinam um termo de autorização do uso de informações pela Câmara dos Deputados, que inclui sua divulgação em qualquer meio existente ou que venha a existir.

${ }^{18} \mathrm{http} / / / \mathrm{www}$. votenaweb.com.br/projetos/plc-7231-2010

${ }^{19}$ Ver http://www.youtube.com/watch?v=kp2tkeE8JLw

${ }^{20} \mathrm{http}: / / \mathrm{www}$. votenaweb.com.br/projetos/plc-7910-2010

21 Ver http://www.brasil.gov.br/cidadania-e-justica/2013/04/brasil-e-o-unico-pais-da-america-latina-que-trabalhacom-formacao-de-caes-guia

${ }^{22}$ http://www.votenaweb.com.br/projetos/plc-7909-2010
} 


\begin{tabular}{|c|c|c|c|c|c|}
\hline $\begin{array}{l}\mathbf{A} \\
\mathbf{n} \\
\mathbf{o}\end{array}$ & Nome $^{23}$ & $\begin{array}{l}\text { Cidade } \\
\text { / UF }\end{array}$ & Ementa & Desdobramentos & Outros \\
\hline ఫ্ণ & $\begin{array}{l}\text { André } \\
\text { Silva }\end{array}$ & $\begin{array}{l}\text { Brasília } \\
\text { (DF) }\end{array}$ & $\begin{array}{l}\text { Todo site de órgão público } \\
\text { deve ter uma página } \\
\text { destinada às crianças, com } \\
\text { explicações sobre o que o } \\
\text { órgão faz e a sua } \\
\text { importância para o país e } \\
\text { para o povo. }\end{array}$ & $\begin{array}{l}\text { A ideia não é objeto de } \\
\text { proposição. No entanto, } \\
\text { diversos órgãos públicos já } \\
\text { têm sites infantis, como o } \\
\text { Ministério Público } \\
\text { (http://www.turminha.mpf. } \\
\text { mp.br/), IBGE } \\
\text { (http://7a12.ibge.gov.br/), } \\
\text { EBC } \\
\text { (http://www.ebc.com.br/inf } \\
\text { antil), STJ } \\
\text { (http://www.stjunior.stj.jus } \\
\text {.br). }\end{array}$ & \\
\hline$\frac{\text { ก }}{\text { ก }}$ & $\begin{array}{l}\text { Mayara } \\
\text { Bezerra }\end{array}$ & $\begin{array}{l}\text { Iracema } \\
(\mathrm{CE})\end{array}$ & $\begin{array}{l}\text { Toda criança tem o direito } \\
\text { de ter identificação com } \\
\text { foto e demais dados dela e } \\
\text { dos pais, desde seu } \\
\text { nascimento. }\end{array}$ & $\begin{array}{l}\text { PL 278/2011 tem igual } \\
\text { teor. }\end{array}$ & \\
\hline 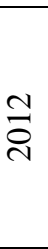 & $\begin{array}{l}\text { Ana } \\
\text { Carolinne } \\
\text { da Silva }\end{array}$ & $\begin{array}{l}\text { Guaraí } \\
\text { (TO) }\end{array}$ & $\begin{array}{l}\text { Garante aos pais o direito } \\
\text { de se ausentar do serviço } \\
\text { para irem à escola dos } \\
\text { filhos } \\
\begin{array}{l}\text { convocação da unidade } \\
\text { escolar. }\end{array}\end{array}$ & $\begin{array}{l}\text { PLS 620/2011 tem igual } \\
\text { teor. }\end{array}$ & \\
\hline$\frac{m}{\delta}$ & $\begin{array}{l}\text { Maila } \\
\text { Santos }\end{array}$ & $\begin{array}{l}\text { Prima- } \\
\text { vera do } \\
\text { Leste } \\
\text { (MT) }\end{array}$ & $\begin{array}{l}\text { Arborização do Programa } \\
\text { Minha Casa, Minha Vida. }\end{array}$ & $\begin{array}{l}\text { Embasou o requerimento } \\
\text { do Dep. Wellington } \\
\text { Fagundes ao Executivo }{ }^{24} \text {. } \\
\text { A proposta é um dos itens } \\
\text { do Selo Azul da Caixa, } \\
\text { banco responsável pelo } \\
\text { Minha Casa, Minha Vida }{ }^{25} \text {. }\end{array}$ & \\
\hline$\frac{m}{\bar{N}}$ & $\begin{array}{l}\text { Ana } \\
\text { Clara } \\
\text { Silva }\end{array}$ & $\begin{array}{l}\text { Belo } \\
\text { Hori- } \\
\text { zonte } \\
\text { (MG) }\end{array}$ & $\begin{array}{l}\text { É obrigatório informar a } \\
\text { quantidade de açúcar } \\
\text { contida nos alimentos, por } \\
\text { meio da tabela nutricional, } \\
\text { em uma nova categoria } \\
\text { denominada "AÇÚCAR". }\end{array}$ & $\begin{array}{l}\text { PL 7141/2014, apensado ao } \\
\text { PL 2356/2003, tem o } \\
\text { mesmo teor. } \\
\text { PL 6451/2009, apensado ao } \\
\text { PL 1350/2007, tem o } \\
\text { mesmo teor. }\end{array}$ & $\begin{array}{l}\text { Recebeu } 88 \% \text { de } \\
\text { votos a favor no } \\
\text { Vote na } W e b^{26}\end{array}$ \\
\hline
\end{tabular}

Fonte: Elaborado pela autora com dados do Plenarinho.

\subsection{Câmara Mirim 2013}

A segunda codificação nesta análise de conteúdo é a aderência ou não dos projetos de lei infantis aos objetivos do Plenarinho. Para esta fase, optou-se pela edição de 2013 do Câmara Mirim. Ao todo, 411 projetos foram inscritos, via portal, e-mail e correios. Farão parte da análise somente os que foram enviados pelo Portal (352 inscrições), pelo fato de o formulário estar

\footnotetext{
${ }^{23}$ Os nomes das crianças estão presentes no Portal Plenarinho e são amplamente divulgados pela mídia interna e externa. Os responsáveis dos vencedores assinam um termo de autorização do uso de informações pela Câmara dos Deputados, que inclui sua divulgação em qualquer meio existente ou que venha a existir.

${ }^{24} \mathrm{Ver}$

<http://www.camara.gov.br/proposicoesWeb/prop_mostrarintegra;jsessionid=12398216AF54E21AA03745455D808 391. node1 ? codteor $=1207380 \&$ filename $=\mathrm{INC}+5554 / 2013>$

${ }^{25}$ Conforme http://mcmv.caixa.gov.br/estudante-quer-tornar-obrigatoria-arborizacao-do-minha-casa-minha-vida/

${ }^{26} \mathrm{http}: / / \mathrm{www}$. votenaweb.com.br/projetos/plc-6451-2009
} 
contextualizado no ambiente do Plenarinho.

As categorias foram levantadas com base nos problemas que as crianças pretendiam resolver com seus projetos de lei. Ao mesmo tempo, esse conteúdo foi avaliado por meio da comparação com o que o Plenarinho dispõe no portal.

\section{Estão aderentes ao conteúdo do Plenarinho:}

- Educação - Há diversas sugestões de inclusão curricular de disciplinas (meio ambiente, direito constitucional, direito do consumidor, direitos humanos, primeiros socorros, etc.) e de valorização do professor, bem como indicações da escola como local de assistência (médica, odontológica, nutricional e psicológica).

- Meio ambiente - Reflorestamento da Mata Atlântica, plantio de uma árvore a cada nascimento, proteção a animais desabrigados são algumas das ideias, que encontram guarida nos materiais do Plenarinho.

- Saúde - Há projetos de melhoria do SUS, mas também preocupações com o tabagismo e com o peso das mochilas, que estão na pauta do Plenarinho.

- Uso da internet para fins políticos e de defesa de direitos - Há desde a proposta de uma rede social virtual onde todos seriam "políticos" à criação de um site para receber denúncias de violência sexual contra crianças e adolescentes. O próprio Portal Plenarinho é uma iniciativa que utiliza a internet para fomentar participação política.

- Fóruns de deliberação - Estabelecimento de espaços democráticos para discussão e resolução de problemas nas escolas, ruas e bairros. Há animações e histórias em quadrinhos do Plenarinho, por exemplo, que trabalham essa questão no ambiente escolar.

- Comportamentos no ambiente em que se vive - Criação de hortas comunitárias, coleta seletiva do lixo, aproveitamento da água, crianças como fiscais do meio ambiente estão entre essas propostas. Elas traduzem possibilidades de atuar politicamente no nível micro, ou seja, descrevem ações exequíveis pelas próprias crianças em suas comunidades, principalmente nas escolas. Trata-se de uma apropriação do fazer político e da consciência da cidadania individual. Este será o princípio norteador para o novo Plenarinho.

- Consciência orçamentária - Alguns projetos demonstram conhecimento sobre aspectos financeiros, tributários e orçamentários da legislação, apontando fontes de recursos e justificativas para isenções fiscais. O jogo mais acessado do Plenarinho é o Jogo do Orçamento, que tem por objetivo introduzir as crianças no assunto.

- Defesa de direitos da infância - Nessa formação discursiva estão projetos que tratam do combate ao bullying e ao abuso sexual. Esses são temas tratados pela Turma do Plenarinho em matérias e revistinhas. Um dos projetos infantis cita o ECA para proteger as crianças indígenas contra a violência sexual, tida como "cultural" em algumas tribos. 
- Proteção aos mais vulneráveis - Esse tópico traz propostas bem criativas, como a adequação da merenda escolar para diabéticos, Escola para idosos, obrigatoriedade do Teste do Pezinho na Alta Hospitalar e a liberação da mulher do trabalho para realização do Papanicolau. Também há projetos para melhorias na acessibilidade e para a assistência aos moradores de rua. A preocupação com os mais vulneráveis mostra que as crianças não precisam guardar identidade com esses públicos, para reconhecer seus direitos e zelar por eles.

\section{Não são pautas do Plenarinho:}

Alguns projetos trazem conteúdos que não são encontrados no Plenarinho, mas são temas de repercussão na discussão política, presentes na propaganda partidária, no jornalismo da grande mídia e nas conversas interpessoais:

- Preocupação com assistencialismo - As propostas das crianças acrescentam mais condições e contrapartidas para o recebimento de benefícios de programas de transferências de renda e seguros. Há, por exemplo, a fixação de tempo máximo para recebimento de bolsas, a obrigatoriedade de trabalho voluntário na vigência do seguro desemprego e ainda o trabalho de presos.

- Redução da maioridade penal - Do total de 352 projetos inscritos pelo Portal, nove pediram a redução da maioridade penal. Esse é um dado curioso, porque mostra crianças punindo outras crianças. Essa posição contradiz a Constituição Federal e o ECA. A insistência da mídia na cobertura de homicídios praticados por menores de idade pode estar na raiz dessa postura de alguns candidatos a deputado mirim.

A terceira codificação nesta análise de conteúdo diz respeito ao letramento político. Procede-se à avaliação de uma amostra dos projetos de lei enviados pelas crianças $^{27}$, tendo por categorias os requisitos de Crick (1998). Foram criadas três matrizes, com 16 valores, nove práticas e 12 conhecimentos (Quadro 1), identificando-se os aspectos de cada projeto atendidos em cada categoria. Trata-se de uma análise mais profunda, que observa conteúdos não manifestos.

A maior parte dos projetos $(74 \%)$ atendeu a metade dos valores ou mais. Como nos valores, a maioria (66\%) cumpriu com mais da metade dos requisitos para as práticas enumeradas por Crick.

Diferentemente dos registros de valores e práticas, os números de requisitos de conhecimento atendidos se aproximaram mais nas amostras, entre os que atenderam a $50 \%$ ou mais e os que atenderam a menos de 50\% - na faixa de 57\%. Esse é um dado interessante, que reduz o peso dos conhecimentos na aquisição de valores e na adoção de práticas democráticas.

\footnotetext{
${ }^{27}$ Amostra de $10 \%$ do total de projetos enviados pelas crianças. Manteve-se a proporção de sexo e de local de origem, para em seguida pinçar os projetos aleatoriamente. Para garantir a representatividade da amostra, e também a aplicabilidade dos requisitos, os dados foram comparados a uma segunda amostra, montada de forma idêntica. Os resultados ficaram bem próximos, o que permite afirmar que o extrato analisado corresponde estatisticamente à "colher de sopa do caldeirão".
} 
$\mathrm{O}$ requisito menos observado (abordado em somente um projeto de cada amostra, e de forma sumária), refere-se ao conhecimento sobre "Parlamentos nos níveis local, estadual, nacional, continental e internacional, incluindo como eles funcionam e se transformam". Esse dado revela que, embora o Portal Plenarinho ofereça uma ampla gama de informações sobre a Câmara dos Deputados e o Poder Legislativo, elas não são mencionadas nos projetos das crianças.

Ao observar os resultados, chega-se a algumas compreensões do letramento político infantil no Câmara Mirim 2013:

- O contexto sócio histórico e político do ano, em especial as jornadas de junho, teve impacto limitado nas propostas enviadas e na escolha dos vencedores.

- Os projetos que não se alinhavam à pauta do Plenarinho também não estavam entre os que atenderam ao maior número dos requisitos de Crick. Suscita-se que as exigências ouvidas nas redes virtuais, nas ruas e na mídia tenham o Estado como destinatário - e responsável para a resolução dos problemas.

- Os projetos que mais atenderam aos requisitos de Crick propõem estatutos novos e trazem a responsabilidade individual no processo político. A criatividade, para além do discurso da mídia, salienta a sensibilidade das crianças para sua realidade.

\section{Desafios do Plenarinho}

\section{Tecnológicos}

Todas as propostas de refinamento e criação objetivam enriquecer ainda mais a experiência de navegação no Plenarinho. Surge, no entanto, um paradoxo: a atratividade do portal pode estimular as crianças a passarem ainda mais tempo na internet, ultrapassando o limiar do que é considerado saudável pelos especialistas.

O segundo paradoxo refere-se à maior porosidade (SILVA, 2009), com a produção de conteúdo pelas crianças (O'REILLY, 2005). O sucesso das ações pode comprometer sua sustentabilidade e mesmo inviabilizá-las, devido à sobrecarga das pessoas que realizam o trabalho de moderação e tratamento desse conteúdo ${ }^{28}$.

O Plenarinho também precisa lidar com a crescente concorrência com outros sites (especialmente os de entretenimento), os jogos on-line e páginas em redes sociais que não se alinham com a educação para a cidadania.

\section{Comunicacionais}

O Plenarinho é mantido por uma instituição formal, o que lhe traz exigências nas abordagens dos assuntos. Várias questões estão em discussão na Casa, e cabe ao programa não

\footnotetext{
${ }^{28}$ A exemplo do Portal E-Democracia da Câmara dos Deputados, analisado por Faria (2012), o suporte do corpo técnico de recursos humanos é fundamental para o Plenarinho.
} 
tomar partido até que sejam transformadas em lei.

Outro cuidado que o Plenarinho precisa tomar está na configuração dos personagens vilões das histórias. Na grande maioria das vezes, eles não são humanos, para que não possam ser associados a nenhum político real, ou ainda a pessoas que façam parte do círculo de convivência das crianças.

No empenho pela proteção da infância, muitas vezes o Plenarinho precisa tratar de temas "que ninguém quer tratar", como o abuso sexual de crianças e adolescentes - não os tendo como referentes da mensagem (quando se fala sobre eles), mas como destinatários (quando se fala para eles). Assim, há conteúdos que são exclusivos do portal.

O Plenarinho realiza um trabalho extremamente delicado, porque lida com o público infantil. Se, por um lado, o programa é fonte de informações positivas sobre a Câmara dos Deputados para a mídia, por outro lado, bastaria um único problema para que o esforço de uma década desmoronasse.

Paira, ainda, uma desconfiança por parte de acadêmicos, políticos e famílias acerca do letramento político infantil, que guarda um limite muito tênue com a doutrinação partidária ou “ideológica”. Ceaser (2013), por exemplo, argumenta em favor da educação cívica, e não política, porque esta poderia desestabilizar "o regime" e causar sérios danos aos valores republicanos e mesmo à democracia.

Como a neutralidade é impossível de se alcançar, o Plenarinho está, potencialmente, na berlinda tanto dos conservadores quanto dos progressistas.

\section{Educacionais}

O próprio sistema educacional é antidemocrático. Professores ressentem-se de não poderem participar das decisões curriculares, tomadas por "burocratas em seus escritórios no Ministério da Educação, que nunca pisaram numa sala de aula" ${ }^{29}$. Por sua vez, os professores relatam que é muito mais fácil dar ordens e exigir obediência das crianças - "criança democrática dá trabalho demais" ${ }^{30}$-, reproduzindo a mesma espiral autoritária a que eles foram submetidos quando crianças e a que ainda estão submetidos, como profissionais do sistema de educação.

A barreira autoritária ou mesmo a resistência ao letramento político não devem impedir que as escolas sejam as principais parceiras do Plenarinho, pelo contrário. Para Lockyer (2008), não é necessário que as escolas (ou as famílias) sejam instituições completamente democráticas para que se admita o engajamento político. Se elas reconhecerem os estudantes como cidadãos, considerando o alcance de seus direitos e responsabilidades, já é o primeiro passo para que a

\footnotetext{
${ }^{29}$ Relato informal de uma professora, durante uma apresentação do Plenarinho em uma escola pública de Sobradinho-DF.

${ }^{30}$ Relato informal de uma professora, durante uma apresentação do Plenarinho em uma escola pública de Sobradinho-DF.
} 
transformação ocorra - partindo das próprias crianças.

\section{Políticos}

É necessário compreender o Plenarinho dentro do contexto da Câmara dos Deputados. De modo geral, os deputados não percebem, no Plenarinho, uma forma de aperfeiçoar o seu trabalho parlamentar. Os poucos que se dispõem a conhecê-lo e têm oportunidade de fazê-lo nutrem simpatia pelo programa, ajudando a divulgá-lo em seu estado, como complemento ao corpo-a-corpo com suas bases, e participam das ações quando são convidados. É fato que as crianças não votam e assim não estariam entre os eleitores dos deputados, a quem geralmente sua atividade é endereçada.

A direção da Casa também encara o Plenarinho com boa vontade e não se nega a contribuir com as ações, seja com recursos financeiros, seja com a logística (que, no Câmara Mirim, envolve muitos setores da administração e da área legislativa, como a Secretaria Geral da Mesa).

No entanto, pelo volume de atividades, o Plenarinho conta com uma equipe pequena ${ }^{31}$. Deve-se lembrar que foi uma iniciativa de servidores, e não de parlamentares, nem da sociedade. Seu desenvolvimento deve ser creditado ao esforço pessoal da equipe em se especializar. Ao mesmo tempo, o programa goza de considerável autonomia.

Kies (2010) reconhece que, para muitos parlamentares, o processo político já é complicado o suficiente para que seja ainda integrado a outras formas de participação popular. Quando essa participação provém de um público que nem sequer é eleitor, é natural que o Plenarinho acabe sendo encarado pela Casa (e pela própria Secretaria de Comunicação Social, à qual está vinculado) como um programa acessório, ainda que angarie simpatia.

Em síntese, as dificuldades mostradas acima são exemplos do que qualquer iniciativa de letramento político infantojuvenil terá que enfrentar, dependendo das atividades que se disponha a executar. Para sites, os desafios da dimensão tecnológica do Plenarinho serão semelhantes. E assim respectivamente, para produtos de comunicação (mídia impressa ou eletrônica, apresentações, etc.) na dimensão comunicacional; e para escolas, na dimensão educacional. A última dimensão é particularmente afeita às instituições estatais, como escolas do Legislativo e programas de parlamentos mirins em estados e municípios.

\section{Conclusões}

Desde sua criação, o Plenarinho, programa de relacionamento da Câmara dos Deputados com o público infantojuvenil, tem evoluído continuamente. Nesse trajeto, observa-se a busca por excelência em quatro dimensões:

\footnotetext{
${ }^{31}$ A equipe do Plenarinho é formada por coordenador, editor-chefe, redator, dois ilustradores, um programador de jogos e dois estagiários de jornalismo
} 
1. Tecnológica - plataforma robusta, segura, versátil, acessível e com usabilidade tanto para os usuários quanto para os gestores, que permita a estruturação dos dados;

2. Comunicacional - conteúdos bem estruturados, em linguagem criteriosa, que faça conexão com a realidade imediata e seja adequada tanto para o público-alvo quanto para os objetivos da instituição;

3. Educacional - elementos simultaneamente lúdicos e educativos, que atendam às crianças e apoiem o professor;

4. Política - cenário amplo, que englobe conceitos, valores, práticas e conhecimentos, conforme proposto por Crick (1998).

Nota-se a crescente abrangência do objetivo principal do programa, deslocando-se o eixo inicial, de informações sobre a Câmara dos Deputados, para o empoderamento do público infantil por meio do letramento político. O legado de mais de dez anos permite que agora o Plenarinho possa se dedicar mais à interação com o público-alvo, com a incorporação de conteúdo colaborativo e a avaliação paulatina das ações.

A internet é preponderante para o Plenarinho, um programa de uma instituição de representação nacional, mas com apenas uma sede, na capital. O foco, no entanto, deixará de ser o acesso pelos computadores, voltando-se para os dispositivos móveis (celulares e tablets), que é por onde a geração atual de crianças utiliza a internet.

Mesmo com a internet, o Plenarinho não abre mão de ações presenciais. São elas que podem acrescentar o aspecto social ao letramento político, conforme recomendado por Arthur e Davison (2000). O Câmara Mirim traz resultados animadores sobre o letramento político das crianças participantes e tende a continuar como carro-chefe do programa. A maioria dos projetos inscritos na edição de 2013 atendeu a mais de 50\% dos requisitos de Crick (1998). O primeiro benefício da participação está na própria oportunidade de participação, reiterando que a orientação prévia para inscrição acrescenta valores, práticas e conhecimentos já de início.

Conhecimentos específicos sobre a Câmara dos Deputados e o Poder Legislativo, tão caros para o Portal Plenarinho desde sua origem, não foram decisivos para a formulação das propostas das crianças. Contudo, conceitos abordados em revistinhas, animações e matérias dos principais temas do programa (Educação, Meio Ambiente e Saúde) estiveram presentes na maior parte dos projetos. Esses temas deram a tônica do Câmara Mirim 2013, enquanto que mesmo as bandeiras das jornadas de junho no Brasil só foram mencionadas no que tangia a eles.

Vários projetos de lei dos candidatos a deputado mirim surpreenderam pela criatividade e pela sensibilidade às questões socioeconômicas, tanto locais como nacionais, em especial a preocupação com setores mais vulneráveis da sociedade.

Mesmo com o êxito em diversos produtos e ações, o Plenarinho precisa enfrentar vários desafios para continuar progredindo, e até existindo. Esses desafios não lhe são exclusivos e se impõem a qualquer programa de letramento político infantojuvenil, o que torna esta análise 
particularmente útil para iniciativas semelhantes.

Dois paradoxos se impõem na dimensão tecnológica, de ordem externa e interna, respectivamente: o sucesso do Plenarinho pode implicar a permanência excessiva das crianças na internet e, ao mesmo tempo, a sobrecarga da equipe no tratamento daquilo que recebe do público. A web também é um ambiente de disputa discursiva, em que apelos de toda ordem representam forte concorrência para a educação cidadã.

Na dimensão educacional, o estreitamento contínuo e crescente com os professores é imperativo, até para que o Plenarinho não tome decisões insulares e distantes da realidade da salade-aula, "com seus burocratas nos seus escritórios com ar condicionado" na capital federal.

Os temas delicados representam risco constante na dimensão comunicacional. Além disso, como o Plenarinho não pode tomar partido de questões em trâmite no Congresso Nacional, fica suscetível a perder a chance de promover o debate com seu público-alvo ou mesmo tornar-se um programa "chapa branca" 32 .

Com sua equipe restrita, o Plenarinho tem alcance pequeno até dentro da Câmara. Vários parlamentares e setores na Casa não conhecem o que o programa faz. De forma geral, os deputados ainda veem o Plenarinho como uma ferramenta de Relações Públicas, tal qual era em sua origem.

Somado ao alcance reduzido na divulgação de suas ações perante o vasto universo infantojuvenil no País, está o fato de que nem sempre as crianças encontram condições para aplicar o que aprendem no letramento político.

Depreende-se, assim, que o Plenarinho permanece no nível latente. Seu potencial é gigantesco, mas seu estágio ainda consiste em plantar sementes. Promisor. Necessário. Para gerações novas e atuais.

\section{Referências}

A HANDBOOK on child participation in Parliament: handbook for parliamentarians N. 18. 2011. Inter-Parliamentary Union e Unesco. Disponível em: <http://www.ipu.org/PDF/publications/child-parl-e.pdf> Acesso em: 12 maio 2014.

ACKERMANN L., FEENY, T, HART, J. \& NEWMAN, J. Understanding \& evaluating children's participation: a review of contemporary literature. Plan UK / Plan International. Out. 2003. Disponível em:

<https://www.plan.org.au/ /media/Documents/Research\%20and\%20Reports/Child_Participatio n_Literature_Review.ashx > Acesso em: 2 abr. 2014.

ARTHUR, J.; DAVISON, J. Social literacy and citizenship education in the school curriculum. The Curriculum Journal, v. 11, n. 1, p. 9-23, Spring 2000.

BABBIE, E. Fundamentos de la investigación social. Mexico: Thompson Editores, 2000.

BANAJI, S.; BUCKINGHAM, D. Young people, the internet, and civic participation: an

\footnotetext{
${ }^{32}$ Diz-se do veículo de comunicação que perde a capacidade crítica, por estar atrelado econômica ou institucionalmente a determinados interesses.
} 
overview of key findings from the CivicWeb Project. International Journal of Learning and Media, v. 2, n. 1, p. 15-24, 2010. Disponível em: <http://eprints.lse.ac.uk/29543/> Acesso em: 12 maio 2014.

BOCCHINO, E. V., SABÁ, C. M. F. O.; SILVA, M. A. B. www.plenarinho.gov.br: não apenas um site, um instrumento a serviço da cidadania. Brasília: Câmara dos Deputados, 2002. Projeto apresentado ao Prêmio Câmara em Ideias - edição 2002 (Programa Mentes em Obra).

BRASIL. Câmara dos Deputados. Projeto de criação do portal infantil da Câmara dos Deputados. Resultado do grupo de trabalho instituído pela Portaria ${ }^{\circ} 7$ de 2003. Brasília: Câmara dos Deputados, 2003.

BRASIL. Câmara dos Deputados. Qual é o objetivo do Plenarinho? (documento interno do Plenarinho). Brasília: Câmara dos Deputados, 2004.

BRASIL. Lei no 8.069, de 13 de julho de 1990. Estatuto da Criança e do Adolescente (ECA). Diário Oficial [da] República Federativa do Brasil, Poder Executivo, Brasília, DF, 16 jul. 1990. Seção 1, p. 13563.

CAUSOS do ECA: histórias que tecem a rede: o Estatuto da Criança e do Adolescente. São Paulo: Fundação Telefônica, 2011. Disponível em:

<http://www.promenino.org.br/Portals/0/CausosdoECA/Causos7/Causos\%20do\%20ECA\%207. pdf> Acesso em: 9 jun. 2014.

CEASER, J. W. The role of political science and political scientists in civic education. Washington: American Enterprise Institute; Program on American Citizenship, 2013.

COSSON, R. Escolas do legislativo, escolas de democracia. Brasília: Câmara Edições Câmara, 2008. Disponível em: <http://bd.camara.gov.br/bd/handle/bdcamara/2662> Acesso em: 15 abr. 2014.

COSTA, A.C.; MELO, A. M. Plenarinho: o jeito criança de ser cidadão. Prisma.com: Revista de Ciências e Tecnologia de Informação e Comunicação, n. 11, p. 1-16, 2010. Disponível em: <http://revistas.ua.pt/index.php/prismacom/article/view/725> Acesso em: 28 maio 2014.

CRICK, B (Org). Education for citizenship and the teaching of democracy in schools. Final report of the Advisory Group on Citizenship. London: Qualifications and Curriculum Authority, 1998. Disponível em: < http://dera.ioe.ac.uk/4385/1/crickreport1998.pdf> Acesso em: 28 maio 2014.

FARIA, C. F. S. O parlamento aberto na era da internet: pode o povo colaborar com o Legislativo na elaboração das leis? Brasília: Edições Câmara, 2012.

FOX, N. H. Teaching (is not) activism. Radical Teacher, n. 94, p. 14-23, Fall 2012.

LOCKYER, A. Education for citizenship: children as citizen and political literacy. In INVERNIZZI, A.; WILLIAMS, J. (Ed). Children and citizenship. London: Sage Publications, 2008.

KIES, Raphaël. Promises and limits of web-deliberation. New York: Palgrave Macmillan, 2010.

O'REILLY, T. What Is Web 2.0: design patterns and business models for the next generation of software. 2005. Disponível em: <http://oreilly.com/web2/archive/what-is-web-20.html> Acesso em: 30 maio 2014.

MARTINS, L. M. Educomunicação para a democracia: o programa Plenarinho e o nível de letramento político infanto-juvenil. $118 \mathrm{f}$. Monografia (Especialização em Instituições e Processos Políticos do Legislativo) -Centro de Formação, Treinamento e Aperfeiçoamento da Câmara dos Deputados, 2012. Disponível em:

<http://bd.camara.gov.br/bd/handle/bdcamara/10032?show=full> Acesso em: 16 mar. 2014

MELO, M. R. M. Educação política para a cidadania: a contribuição da Câmara dos 
Deputados. 143 f. Monografia (Especialização em Instituições e Processos Políticos do Legislativo) - Centro de Formação, Treinamento e Aperfeiçoamento da Câmara dos Deputados, 2008. Disponível em: <http://bd.camara.gov.br/bd/handle/bdcamara/383> Acesso em: 16 mar. 2014.

MONTEIRO, T. Oralidade e cidadania: alunos da Escola Estadual Maroja Neto, de Belém (PA), ganham voz e voto no Projeto Câmara Mirim. E-legis: Revista do Programa de Pós-Graduação da Câmara dos Deputados, v. 8, n. 16, p. 96-107, jan./abr., 2015. Disponível em <http://elegis.camara.leg.br/cefor/index.php/e-legis/article/view/202>. Acesso em: 25 nov. 2015.

PINHO, J. B. Propaganda institucional. São Paulo: Summus, 1990.

PLENARINHO. Câmara dos Deputados. Disponível em: < www.plenarinho.leg.br> Acesso em: 3 mar. 2014.

SANTOS, G. L. Tablets, laptops, computadores e crianças pequenas: novas linguagens, velhas situações na educação infantil. Brasília: Liber Livros, 2012.

SILVA, S. P. Estado, democracia e internet: requisitos democráticos e dimensões analíticas para a interface digital do Estado. $424 \mathrm{f}$. Tese (Doutorado em Comunicação e Culturas Contemporâneas) - Faculdade de Comunicação, Universidade Federal da Bahia, 2009. Disponível em: <https://repositorio.ufba.br/ri/handle/ri/5211> Acesso em: 20 maio 2014.

STOCKDALE, R.; BOROVICKA, M. Using Quality Dimensions in the Evaluation of Websites. Information and Communication Technologies in Tourism. Innsbruck: Innsbruck University School of Management, 2006. Disponível em: <http://www.researchgate.net/> Acesso em: 17 maio 2014.

TIC DOMICÍLIOS 2012. São Paulo: Comitê Gestor da Internet no Brasil, 2013. Disponível em: <http://www.cetic.br/usuarios/tic/2012/apresentacao-tic-domicilios-2012.pdf >. Acesso em: 21 maio 2014.

TIC EDUCAÇÃO 2012. São Paulo: Comitê Gestor da Internet no Brasil, 2013. Disponível em: $<$ http://www.cetic.br/educacao/2012/apresentacao-tic-educacao-2012.pdf > Acesso em: 21 maio 2014.

TIC KIDS ONLINE BRASIL 2012: pesquisa sobre o uso da internet por crianças e adolescentes no Brasil. São Paulo: Comitê Gestor da Internet no Brasil, 2013. Disponível em: <http://www.cetic.br/publicacoes/2012/tic-kids-online-2012.pdf> Acesso em: 21 maio 2014.

Artigo recebido em: 26/10/2015

Artigo aceito para publicação em: 04/01/2016 